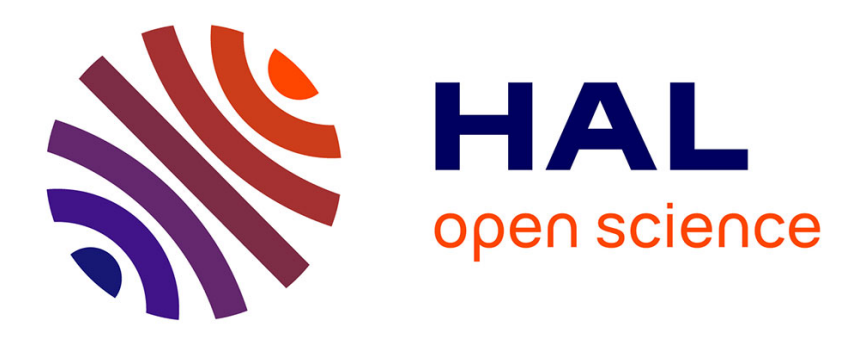

\title{
Asymmetric Zinc Catalysis in Green One-Pot Processes Hélène Pellissier
}

\section{To cite this version:}

Hélène Pellissier. Asymmetric Zinc Catalysis in Green One-Pot Processes. Current Organic Chemistry, 2021, 25, 10.2174/1385272825666210216123607 . hal-03205978

\section{HAL Id: hal-03205978 https://hal.science/hal-03205978}

Submitted on 22 Apr 2021

HAL is a multi-disciplinary open access archive for the deposit and dissemination of scientific research documents, whether they are published or not. The documents may come from teaching and research institutions in France or abroad, or from public or private research centers.
L'archive ouverte pluridisciplinaire HAL, est destinée au dépôt et à la diffusion de documents scientifiques de niveau recherche, publiés ou non, émanant des établissements d'enseignement et de recherche français ou étrangers, des laboratoires publics ou privés. 


\title{
Asymmetric Zinc Catalysis in Green One-Pot Processes
}

\author{
Hélène Pellissier ${ }^{1, *}$ \\ ${ }^{1}$ Aix-Marseille Univ, CNRS, Centrale Marseille, iSm2, Marseille, France
}

\begin{abstract}
This review collects for the first time enantioselective one-pot processes promoted by green chiral zinc catalysts. It illustrates how much these cheap, non-toxic and environmentally benign catalysts allow unprecedented asymmetric domino and tandem reactions of many types to be achieved, allowing direct access to a wide variety of very complex chiral molecules.
\end{abstract}

Keywords: Asymmetric one-pot reactions; asymmetric domino reactions; asymmetric tandem reactions; asymmetric zinc catalysis; metal catalysis; chirality.

\section{INTRODUCTION}

With the aim of conciliating efficient sustainable chemical production with safeguarding human health as well as environment, organic chemists have taken a decisive step in the last decades towards green catalytic synthesis. In this context, the development of novel, nontoxic and effective catalytic systems capable of driving value-added chemical transformations in environmentally benign conditions has become an urgent challenge [1-3]. As a cheap, abundant [4] and less toxic metal in comparison with many transition metals employed in catalysis [5], zinc has gained significant importance in green catalysis. While underdeveloped for a long time, zinc catalysts are more and more applied as Lewis acid complexes to promote all types of more economical and ecological transformations spanning from simple reactions [6] to more sophisticated domino and tandem processes, allowing very complex molecules to be synthesized in a single vessel without costly isolation and purification of intermediates [7]. Among these one-pot reactions are powerful domino processes occurring under strictly the same reaction conditions [8] and combining these simple methodologies with asymmetric zinc catalysis perfectly suit the growing demand for more efficient and environmentally benign synthesis. This interest has resulted in a spectacular development of highly enantioselective zinc-catalyzed one-pot processes in the last decade that this review intends to collect for the first time. Zinc is an essential element for life with high biological importance $[9,10]$, since it is present as a co-catalyst in more than 300 enzymes and 1000 transcription factors [11], which has inspired chemists to design artificial zinc chiral catalysts. Actually, zinc is the second most abundant trace metal in humans after iron and it is the only metal which appears in all enzyme classes [12]. In proteins, zinc is coordinated to the amino acid side chains of aspartic acid, glutamic acid, cysteine and histidine [13]. Zinc becomes toxic above an overdose of around $50 \mathrm{mg}$ in- gested. The consequence of excessive absorption of zinc is the suppression of copper and iron absorption. The free zinc ion in solution is highly toxic to bacteria, plants, invertebrates and vertebrate fishes [14-16].

On the other hand, zinc constitutes an essential trace metal with very low toxicity in humans with a daily dose of $12-15 \mathrm{mg}[17,18]$. In the area of asymmetric catalytic applications of zinc, a wide diversity of chiral zinc complexes have been developed and employed to promote many reactions, reflecting that of the processes disclosed. A range of chiral ligands, including semi-aza-crown ligands, bis(oxazoline)s, bis(imidazoline)s, $N, N^{\prime}$ '-dioxides, 1,1'-bi-2naphthol (BINOL) derivatives, diamines, amino alcohols, cinchona alkaloids, among others, have been already chelated to zinc. It must be noted that the field of asymmetric zinc-catalyzed reactions of all types was most recently updated by Mlynarski in 2015 including only three references concerning asymmetric domino processes [19]. Moreover, the more general field of zinc catalysis (not especially asymmetric) was reviewed by Enthaler and $\mathrm{Wu}$ the same year [20]. Also in 2015 Lee and Bouffard reported the field of tandem reactions based on the use of organozinc reagents, albeit with no reference dealing with asymmetric zinc-catalyzed tandem reactions [21]. In 2019, a review on the synthesis of heterocycles via zinc catalysis was published by Beller and Anilkumar, including no reference concerning asymmetric work [22]. In 2020, Anilkumar reviewed zinc-catalyzed multicomponent reactions but with only one asymmetric work [23]. Even if the general field of asymmetric metal-catalyzed domino reactions has been the subject of precedent reviews covering the literature up to 2018 [5p,w-x], it must be noted that the largest share of activity in enantioselective zinccatalyzed one-pot reactions dated after 2018. This demonstrates that this special and original field has blossomed in very recent years to become an area in its own right, deserving a special review. The present review is divided into six parts according to the type of chiral ligands employed to promote the reactions, highlighting successively semi-aza-crown ligands, bis(oxazoline)s and bis(imidazoline)s, $N, N$ '-dioxides, BINOL derivatives, 1,2-diamines, and other 
ligands. The low price of zinc makes zinc catalysis suiting the growing demand for greener processes and offers the real opportunity to replace other toxic and expensive metals in the near future. This review demonstrates that zinc brings a novel potential for green catalysis when combined with complex asymmetric one-pot processes and that this original area is growing very rapidly.

\section{REACTIONS USING SEMI-AZA-CROWN LIGANDS}

\subsection{ProPhenol Ligand and Derivatives}

ProPhenol is a semi-aza-crown ligand [24], which was firstly developed in 2000 by Trost and Ito and applied to promote asymmetric zinc-catalyzed aldol reactions [25]. The authors showed that this ligand generated, in the presence of diethyl zinc, a dinuclear bifunctional zinc catalyst $\mathrm{Zn}_{2} \mathrm{Et}$ (ProPhenol) 1 (Scheme 1), possessing both a Brønsted base site and a Lewis acid site embedded within a chiral pocket formed by the ProPhenol ligand. In the aldol reaction, one zinc atom bound to the enolate form of the ketone substrate while the second zinc atom chelated the aldehyde/ketone substrate. The aldol condensation in the chiral pocket formed by the semi-crown ligand was achieved with enantioselectivities of up to $99 \%$ ee and high yields. Later, Trost's ligand was successfully applied to many types of other enantioselective zinc-catalyzed reactions [26], including Henry reaction [27], Mannich reactions [28], Michael additions [29], alkynylations of carbonyl compounds [30], Friedel-Crafts reactions [31], among others. In 2012, Trost and Hirano also demonstrated the use of this ligand to catalyze more complex asymmetric reactions, such as enantioselective domino Michael/lactonization reaction between 3-hydroxyoxindoles 2 and $\alpha, \beta$-unsaturated esters 3 [32]. This process, performed in the presence of $5 \mathrm{~mol} \%$ of $(R, R)$-ProPhenol as ligand and $10 \mathrm{~mol} \%$ of $\mathrm{ZnEt}_{2}$ in a mixture of toluene and acetonitrile as solvent, afforded at $40{ }^{\circ} \mathrm{C}$ the corresponding chiral spirocyclic oxindoles 4 in moderate to excellent yields (38-98\%), diastereoselectivities ( $40-86 \% \mathrm{de})$ and enantioselectivities $(47-99 \%$ ee), as illustrated in Scheme 1. A range of variously substituted phenyl groups $\left(R^{2}\right)$ were tolerated on the $\alpha, \beta$-unsaturated esters, providing spirocyclic $\delta$-lactones 4 in uniformly excellent enantioselectivities ( $92-99 \%$ ee), good to high yields (65-89\%) albeit combined with variable diastereoselectivities (52-86\% de) dependent on the electronic properties of the substituents on the phenyl ring. Excellent results (72-98\% yield, $58-72 \%$ de, $95-98 \%$ ee) were also obtained in the reaction of esters bearing heteroaromatic substituents. On the other hand, alkyl-substituted esters $\left(\mathrm{R}^{2}=\mathrm{Me}, c-\mathrm{Pr}\right)$ provided lower enantioselectivities $(54-75 \%$ ee) and yields (38-67\%) combined with moderate diastereoselectivities $\left(40-62 \%\right.$ de). A ferrocenyl-substituted ester $\left(\mathrm{R}^{2}=1\right.$-ferrocenyl $)$ also underwent the domino process with $55 \%$ yield, $84 \%$ de and $96 \%$ ee while the reaction of an ynenoate $\left(\mathrm{R}^{2}=\right.$ TIPS-C $\left.\equiv \mathrm{C}\right)$ was performed with $84 \%$ yield, $84 \%$ de and $76 \%$ ee. It was found that $\beta, \gamma, \delta$-unsaturated esters $\left(\mathrm{R}^{2}=(E)-\mathrm{PhCH}=\mathrm{CH},(E)-\mathrm{MeCH}=\mathrm{CH}\right)$ also yielded the conjugated products exclusively in excellent enantioselectivities (97-98\% ee), high yields (82-83\%) and moderate to good diastereoselectivities $(42-74 \%$ de). The lowest enantioselectivity $\left(47 \%\right.$ ee) was obtained in the reaction of phenyl acrylate $\left(R^{2}=H\right)$, which gave the corresponding product with $67 \%$ yield. Moreover, different nitrogen protecting groups $\left(\mathrm{R}^{1}\right)$ on the 3-hydroxyoxindoles were tolerated, including methyl, allyl, methoxymethyl, benzyl and p-methoxybenzyl.

To explain these results, the authors proposed the catalytic cycle depicted in Scheme 2. In a first time, 3-hydroxyoxindole 2 was deprotonated by an ethylzinc species to give intermediate $\mathbf{A}$. Then, $\alpha, \beta$-unsaturated ester $\mathbf{3}$ coordinated to the less hindered zinc atom to form intermediate $\mathbf{B}$, which tautomerized into intermediate $\mathbf{C}$. The latter subsequently underwent intramolecular transesterification to release the final spirocyclic oxindole $\mathbf{4}$ and regenerate the zinc phenoxide species $\mathbf{D}$ that could deprotonate another equivalent of 3hydroxyoxindole.

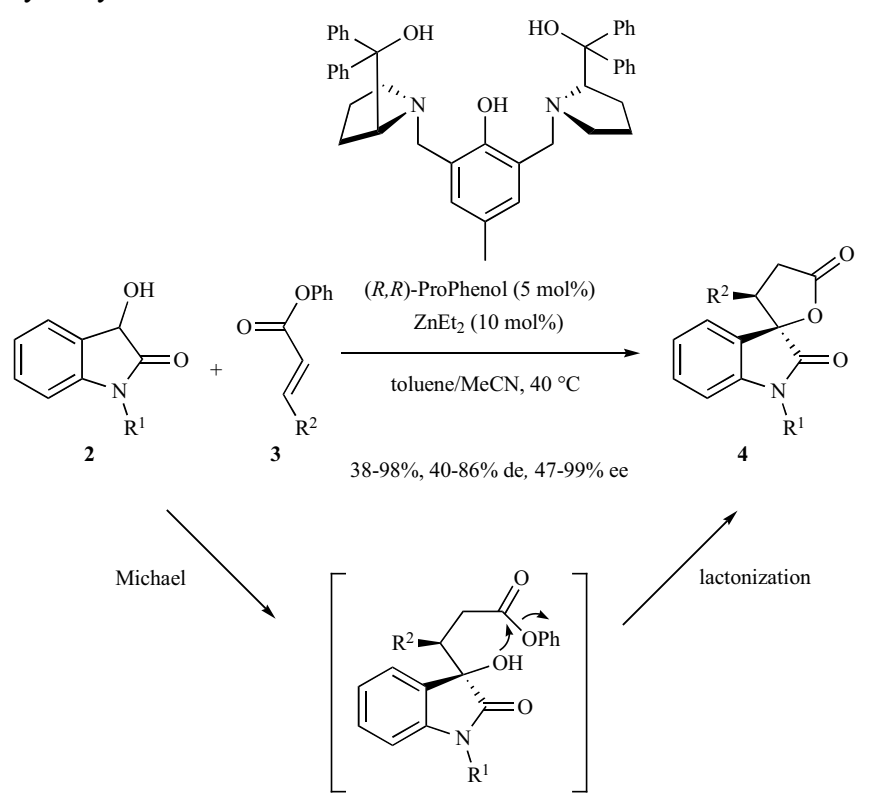

$\mathrm{R}^{1}=\mathrm{Me}$, allyl, MOM, Bn, PMB

$\mathrm{R}^{2}=\mathrm{Ph}, p-\mathrm{MeOC}_{6} \mathrm{H}_{4}, p-\mathrm{ClC}_{6} \mathrm{H}_{4}, p-\mathrm{NCC}_{6} \mathrm{H}_{4}, 3,5-(\mathrm{MeO})_{2} \mathrm{C}_{6} \mathrm{H}_{3}, 3,5-\mathrm{Br}_{2} \mathrm{C}_{6} \mathrm{H}_{3}$, $o$ - $\mathrm{ClC}_{6} \mathrm{H}_{4}, 1$-Naph, 1-furyl, 2-furyl, 1-thienyl, 1-ferrocenyl, $(E)-\mathrm{PhCH}=\mathrm{CH}$, $(E)-\mathrm{MeCH}=\mathrm{CH}, \mathrm{TIPS}-\mathrm{C} \equiv \mathrm{C}, c-\mathrm{Pr}, \mathrm{Me}, \mathrm{H}$

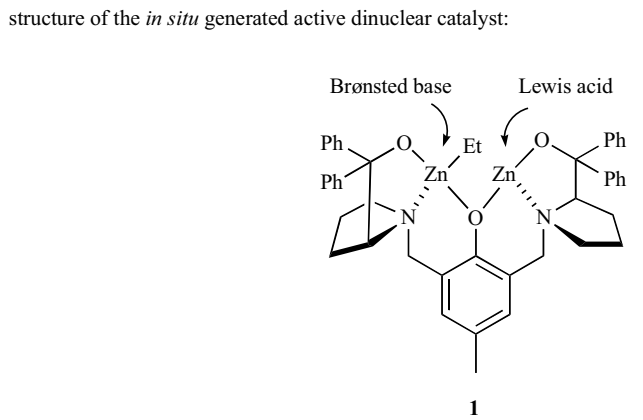

Scheme 1. Domino Michael/lactonization reaction of 3-hydroxyoxindoles with $\alpha, \beta$-unsaturated esters.

In 2013, Marek et al. reported asymmetric alkynylation of acyl silanes 5 with alkyne 6 promoted by 2.4 equivalents of $\mathrm{ZnEt}_{2}$ and 5 $\mathrm{mol} \%$ of $(S, S)$-ProPhenol in toluene at 5 to $15{ }^{\circ} \mathrm{C}$, leading in a onepot operation to propargylic alcohols 7 after subsequent addition of an electrophile (EX) followed by oxidation [33]. Actually, the first step of the sequence consisted of a tandem alkynylation/Brook rearrangement/ene-allene cyclization of acyl silanes 5 with alkyne $\mathbf{6}$, providing intermediate $\mathbf{G}$. As depicted in Scheme 3, the zincpromoted asymmetric alkynylation led to chiral zinc intermediate E, which then underwent a Brook rearrangement to give allenyl zinc intermediate $\mathbf{F}$. Then, the latter was submitted to zincpromoted ene-allene cyclization, leading to cyclic zinc intermediate $\mathbf{G}$. The addition of an electrophile (EX) trapped $\mathbf{G}$ into functionalized product $\mathbf{8}$ which was subsequently oxidized in the presence of aqueous hydrogen peroxide $\mathrm{H}_{2} \mathrm{O}_{2}$ with concomitant desilylation into final acyclic product 7 . This tandem alkynylation/Brook rearrangement/ene-allene cyclization/electrophile addition/oxida- 
tion sequence performed in one-single vessel allowed a range of chiral propargylic alcohols 7 to be synthesized as single diastereomers $(>96 \% \mathrm{de})$ in good yields $(56-83 \%)$ and high enantioselectivities $(76-90 \%$ ee).

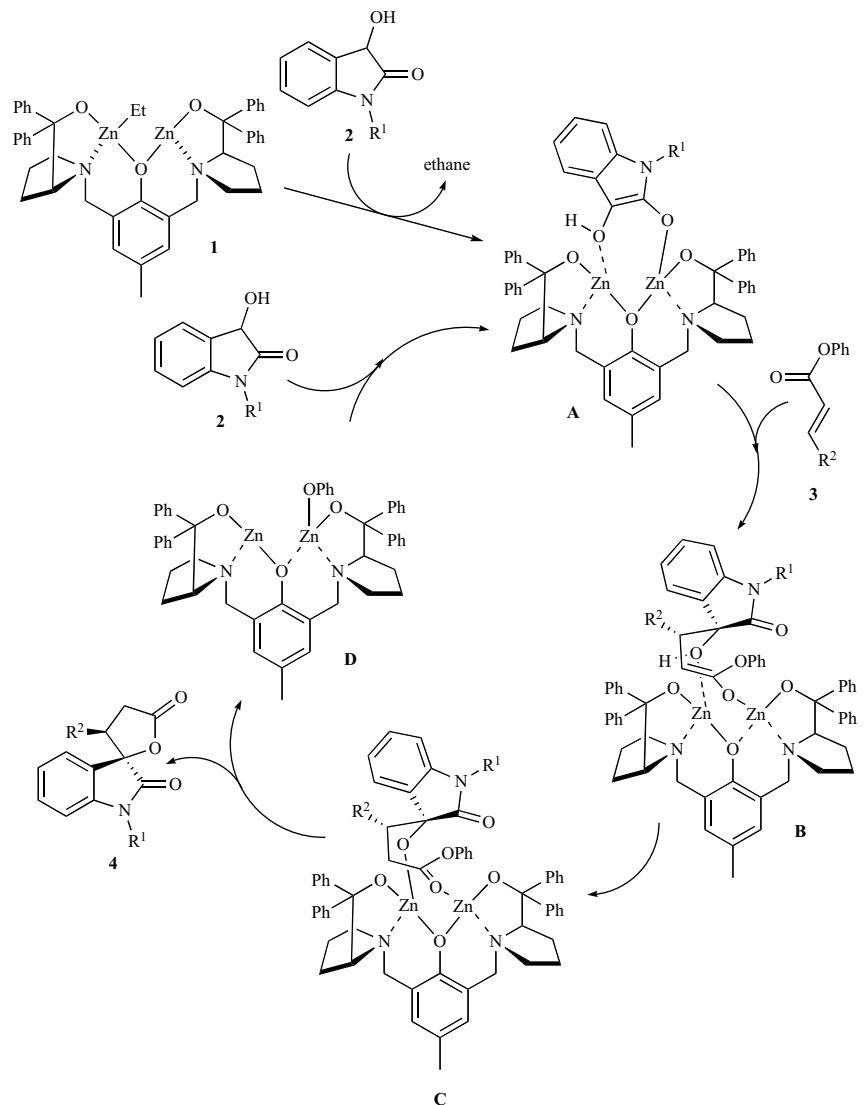

Scheme 2. Catalytic cycle for domino Michael/lactonization reaction of 3hydroxyoxindoles with $\alpha, \beta$-unsaturated esters.

In 2014, Chang et al. reported the use of $(S, S)$-ProPhenol in an enantioselective zinc-catalyzed domino Michael/hemiketalization reaction of cyclic 1,3-diketones 9 with aryl-substituted $\beta, \gamma$ unsaturated $\alpha$-ketoesters 10 [34]. The sequence was performed at $10{ }^{\circ} \mathrm{C}$ in tetrahydrofuran (THF) as a solvent in the presence of 10 $\mathrm{mol} \%$ of $\mathrm{ZnEt}_{2}$ and $5 \mathrm{~mol} \%$ of $(S, S)$-ProPhenol. It yielded the corresponding chiral chromenes $\mathbf{1 1}$ in both uniformly high yields (8596\%) and enantioselectivities (76-94\% ee), as shown in Scheme 4. The yields were found lower when the steric hindrance of the ester group $\left(\mathrm{R}^{1}\right)$ increased. Different substituents on the phenyl ring of the aryl-substituted $\beta, \gamma$-unsaturated $\alpha$-ketoester were tolerated in both meta and para positions, providing high yields and enantioselectivities, whereas ortho-substituted aryl substrates afforded very low yields $(\leq 7 \%)$ because of steric reasons. To explain the stereoselectivity of the reaction, a transition state is proposed in Scheme 4, in which the cyclic 1,3-diketone activated by the Brønsted basic zinc nucleus formed the corresponding zinc enolate. Meanwhile, the $\beta, \gamma$-unsaturated $\alpha$-ketoester was activated by the other Lewis acidic zinc nucleus through bidentate coordination of the 1,2dicarbonyl moiety. In these conditions, the zinc enolate attacked from the $R e$ face of the coordinated Michael acceptor.

In 2018, Trost et al. described an enantioselective tandem Mannich/aldol reaction of branched aldehydes $\mathbf{1 2}$ with $\mathrm{N}$ benzyloxycarbonyl (Cbz)-protected aromatic aldimines $\mathbf{1 3}$ and ketones 14 catalyzed by a combination of $10 \mathrm{~mol} \%$ of $(R, R)$ ProPhenol ligand and $20 \mathrm{~mol} \%$ of $\mathrm{ZnEt}_{2}$ in toluene at $-10{ }^{\circ} \mathrm{C}$ [35].
This one-pot reaction required the separated addition of ketones $\mathbf{1 4}$ into the reaction vessel upon completion of the asymmetric Mannich process (Scheme 5). It delivered the corresponding chiral 1,3aminoalcohols 15 exhibiting three contiguous stereocenters in good yields (71-82\%), combined with both high diastereo- $(82->90 \% \mathrm{de})$ and enantioselectivities $(98-99 \%$ ee). The same catalyst system could be applied to related enantioselective tandem Mannich/Henry reaction of $\mathrm{N}-\mathrm{Cbz}$ protected aromatic aldimines $\mathbf{1 3}$, branched aldehydes $\mathbf{1 2}$ and nitromethane $\mathbf{1 6}$ as added nucleophilic third partner, affording the corresponding chiral 1,3-aminoalcohols $\mathbf{1 7}$ as single diastereomers $(>90 \%$ de) in excellent enantioselectivities $(96-99 \%$ ee) and high yields (72-88\%), as presented in Scheme 5 .
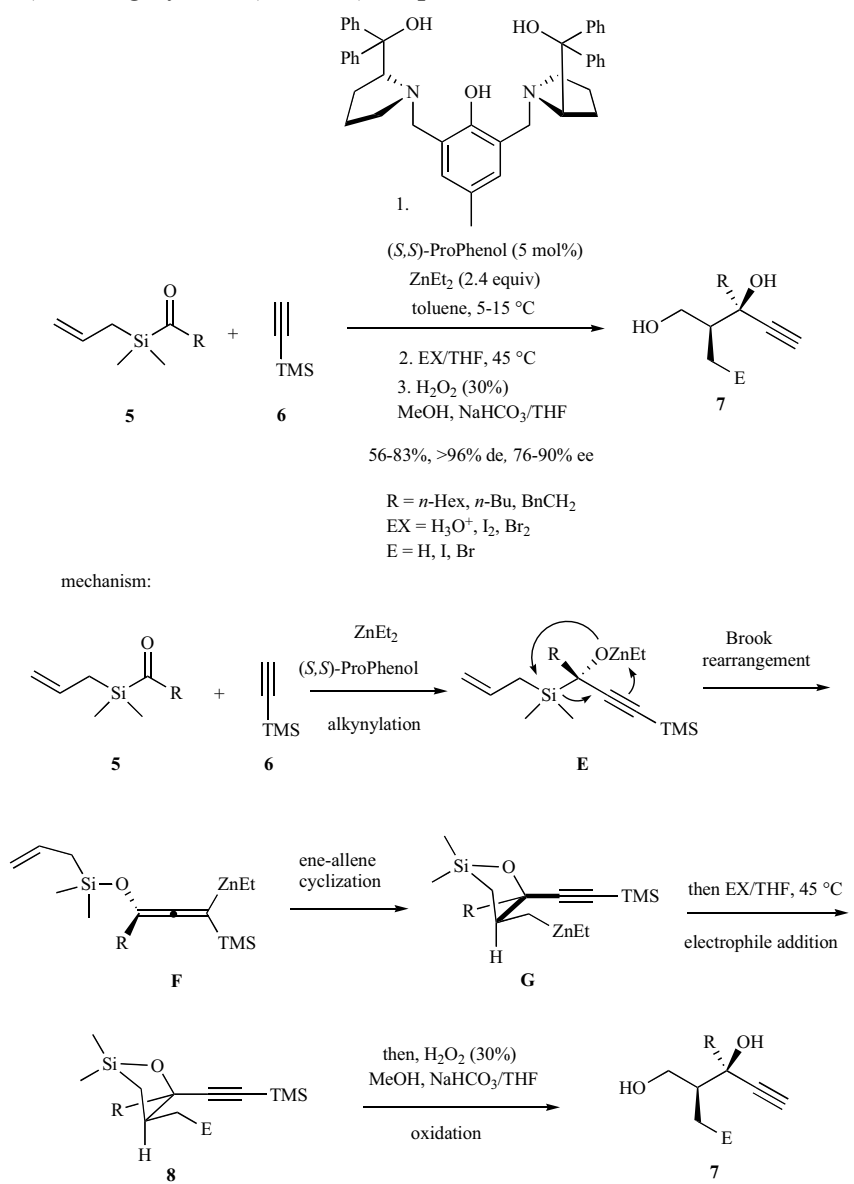

Scheme 3. Tandem alkynylation/Brook rearrangement/ene-allene cyclization reaction followed by electrophile addition and oxidation.

Later in 2019, the same authors developed an enantioselective zinc-catalyzed tandem Mannich/cycloisomerization reaction of $\mathrm{N}$ protected aldimines $\mathbf{1 3 , 1 8}$ with alkynones 19 performed in the presence of $10 \mathrm{~mol} \%$ of $(S, S)$-ProPhenol and $20 \mathrm{~mol}^{\circ}$ of $\mathrm{ZnEt}_{2}$ in THF at room temperature [36]. The Mannich reaction led to intermediate $\beta$-amino ynone 20, which was subsequently cycloisomerized at 75 ${ }^{\circ} \mathrm{C}$ in toluene as a solvent to afford pyrrolidones $\mathbf{2 1}$ after the addition of $10 \mathrm{~mol} \%$ of $\mathrm{PPh}_{3}$ and $40 \mathrm{~mol} \%$ of acetic acid (AcOH). The chiral products were obtained with a good $E / Z$ selectivity (up to $9: 1)$ with good to high yields $(66-87 \%)$ and enantioselectivities (7099\% ee), as shown in Scheme 6. $\mathrm{N}$-Cbz-protected aldimines provided comparable results as $N$-tert-butoxycarbonyl (Boc) derivatives in terms of yields and enantioselectivities. A range of aromatic aldimines exhibiting neutral or electron-rich substituents on the phenyl ring gave uniformly excellent enantioselectivities (83-99\% ee) while the lowest enantioselectivity $(70 \%$ ee) was obtained in the 
reaction of a heteroaromatic aldimine $\left(\mathrm{R}^{1}=1\right.$-furyl). Moreover, a vinyl aldimine $\left(\mathrm{R}^{1}=(E)-\mathrm{PhCH}=\mathrm{CH}\right)$ was cyclized with $68 \%$ yield and $87 \%$ ee. In contrast, the reaction of $c$-propyl aldimine $\left(\mathrm{R}^{1}=c\right.$ Pr) required the use of a more nucleophilic catalyst, such as methyldiphenylphosphine $\left(\mathrm{MePPh}_{2}\right)$ instead of triphenylphosphine $\left(\mathrm{PPh}_{3}\right)$, to promote the cycloisomerization, leading to the corresponding pyrrolidone in $79 \%$ yield and $92 \%$ ee. Interestingly, heterocyclic chiral spirocycles, such as a tetrahydropyran $\left(\mathrm{R}^{2}, \mathrm{R}^{3}=\right.$ $\left.\left(\mathrm{CH}_{2}\right)_{2} \mathrm{O}\left(\mathrm{CH}_{2}\right)_{2}\right)$ and an $N$-Boc piperidine $\left(\mathrm{R}^{2}, \mathrm{R}^{3}=\right.$ $\left.\left(\mathrm{CH}_{2}\right)_{2} \mathrm{NBoc}\left(\mathrm{CH}_{2}\right)_{2}\right)$, could be synthesized with good yields $(86$ and $66 \%$, respectively) and high enantioselectivities (92 and $82 \%$ ee, respectively).<smiles>CCOC(=O)C=C[Al]</smiles>

10<smiles>[R]C1([R])CC(=O)CC(=O)C1</smiles>

9

$\mathrm{R}^{1}=\mathrm{Me}, \mathrm{Et}, i$-Pr

$\mathrm{R}^{2}=\mathrm{H}, \mathrm{Me}$

$\mathrm{Ar}=\mathrm{Ph}, p$ - Tol, $p$ - $\mathrm{MeOC}_{6} \mathrm{H}_{4}, p-\mathrm{FC}_{6} \mathrm{H}_{4}, p-\mathrm{ClC}_{6} \mathrm{H}_{4}, p-\mathrm{BrC}_{6} \mathrm{H}_{4}, m-\mathrm{Tol}, m-\mathrm{ClC}_{6} \mathrm{H}_{4}$, $m$ - $\mathrm{BrC}_{6} \mathrm{H}_{4}, 2$-thienyl, 2-Naph, 3,4- $-\mathrm{OCH}_{2} \mathrm{OC}_{6} \mathrm{H}_{3}, 3-\mathrm{Br}-4-\mathrm{ClC}_{6} \mathrm{H}_{3}$

transition state:

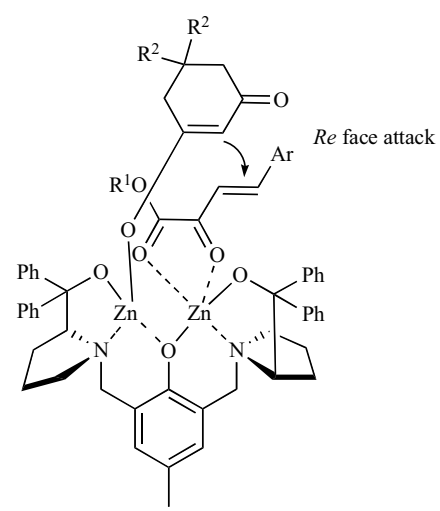

Scheme 4. Domino Michael/hemiketalization reaction of cyclic 1,3diketones with aryl-substituted $\beta$, $\gamma$-unsaturated $\alpha$-ketoesters.

In 2020, a combination of $5 \mathrm{~mol} \%$ of $(S, S)$-ProPhenol with 10 $\mathrm{mol} \%$ of $\mathrm{ZnEt}_{2}$ was used at room temperature in THF as a solvent to promote an asymmetric pseudo-three-component process between two equivalents of $N$-protected aldimines 13,18 and ynones 22 [37]. This remarkable reaction evolved through a domino double Mannich reaction, yielding enantiopure 1,3-diamines 23 (>99\% ee) in good to excellent yields (61-92\%). Moreover, in all cases of substrates, the domino products were obtained as almost single diastereomers $(>90 \%$ de), as shown in Scheme 7 . In addition to a range of (hetero)aromatic aldimines which all delivered the enantiopure domino products, nonaromatic aldimines, such as cyclopropyl imine $(\mathrm{R}=c-\mathrm{Pr})$, underwent the double Mannich reaction with $78 \%$ yield and remarkable enantio- and diastereoselectivities ( $>90 \%$ de, $>99 \%$ ee). Various (hetero)aromatic ynones were compatible to the catalyst system.

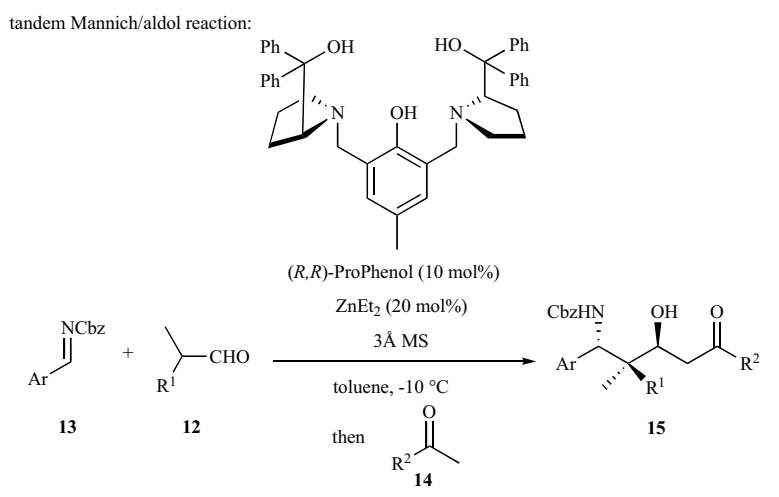

$71-82 \%, 82->90 \%$ de, $98-99 \%$ ee

$$
\begin{aligned}
& \mathrm{Ar}=p-\mathrm{FC}_{6} \mathrm{H}_{4}, m-\mathrm{Tol}, o-\mathrm{BrC}_{6} \mathrm{H}_{4}, o-\mathrm{Tol} \\
& \mathrm{R}^{1}=\mathrm{Me}, \mathrm{Ph} \\
& \mathrm{R}^{2}=\mathrm{TMS}-\mathrm{C} \equiv \mathrm{C}, \mathrm{Ph}-\mathrm{C} \equiv \mathrm{C}, \mathrm{Ph}, \mathrm{TBS}\left(\mathrm{CH}_{2}\right)_{3} \mathrm{C} \equiv \mathrm{C},(1-\text { cyclohexenyl)-C } \equiv \mathrm{C}
\end{aligned}
$$

mechanism:

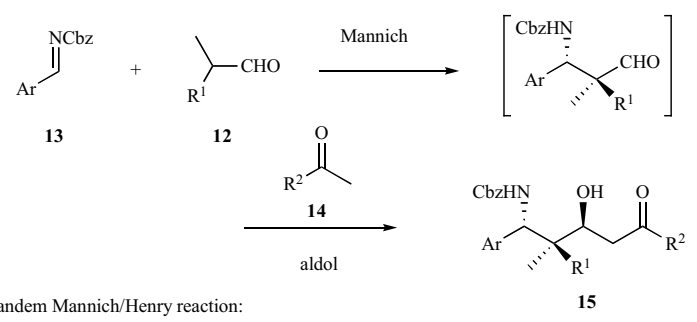

tandem Mannich/Henry reaction:

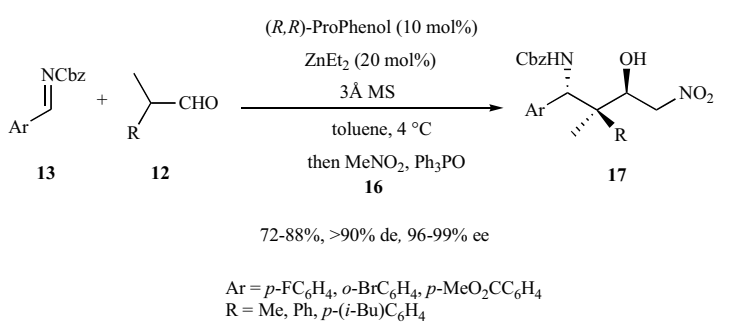

Scheme 5. Tandem Mannich/aldol reaction of branched aldehydes, aromatic aldimines and ketones and tandem Mannich/Henry reaction of branched aldehydes, aromatic aldimines and nitromethane.

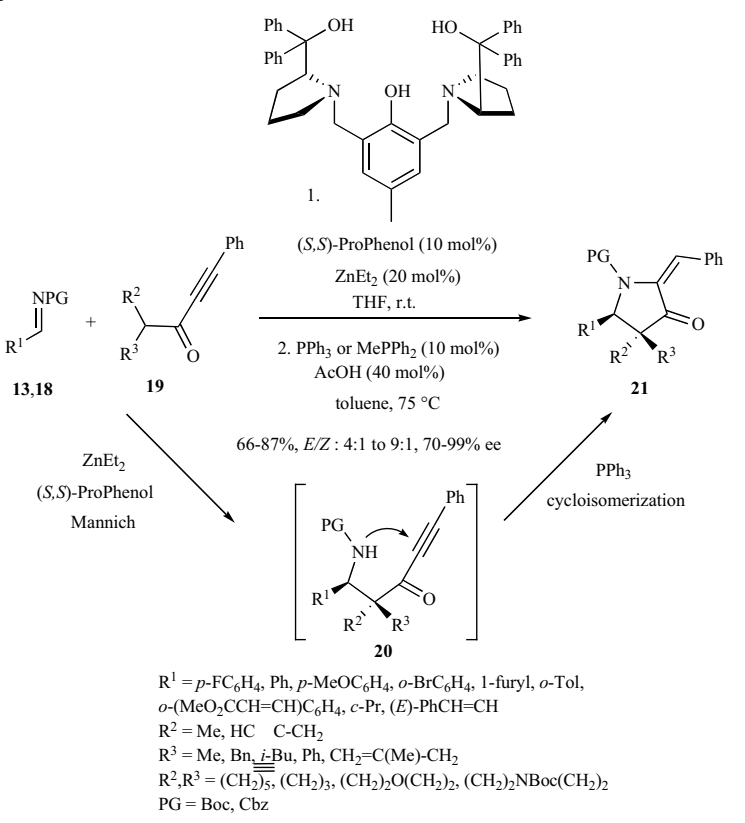

Scheme 6. Tandem Mannich/cycloisomerization reaction of aldimines with alkynones. 


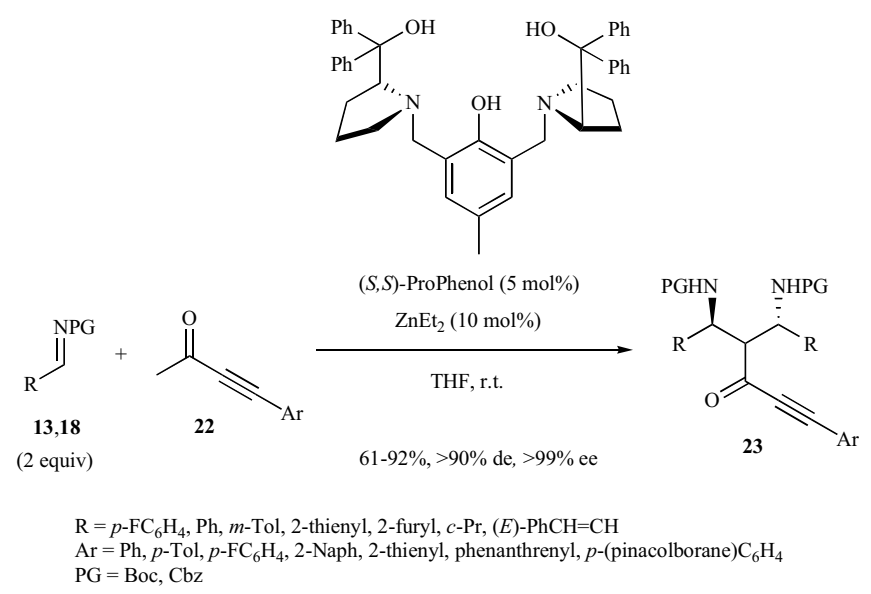

Scheme 7. Pseudo-three-membered domino double Mannich reaction of ynones with aldimines.

Earlier in 2019, ProPhenol derivative ligand 24 (10 mol\%) was combined to $\mathrm{ZnEt}_{2}(20 \mathrm{~mol} \%)$ to promote in toluene at $25{ }^{\circ} \mathrm{C}$ an enantioselective domino phospha-Michael/Michael reaction between $o$-dienones 25 and dialkyl phosphates 26 [38]. The reaction afforded the corresponding chiral biologically interesting 1,2,3trisubstituted indane derivatives $\mathbf{2 7}$, bearing phosphoryl groups and three contiguous stereocenters, as single diastereomers $(>98 \%$ de) in good to high yields (65-92\%) and uniformly excellent enantioselectivities (94->99\% ee), as illustrated in Scheme 8. Various dialkyl phosphates were compatible with the catalytic system, providing homogeneously excellent results (96-99\% ee). Furthermore, comparable excellent yields and enantioselectivities were achieved in the reaction of a series of aryl substituted $o$-dienones, regardless of the electronic nature of the substituents present in the aryl group $\left(\mathrm{Ar}^{2}\right)$. This work constituted a rare example of enantioselective double Michael domino reactions catalyzed by metals.

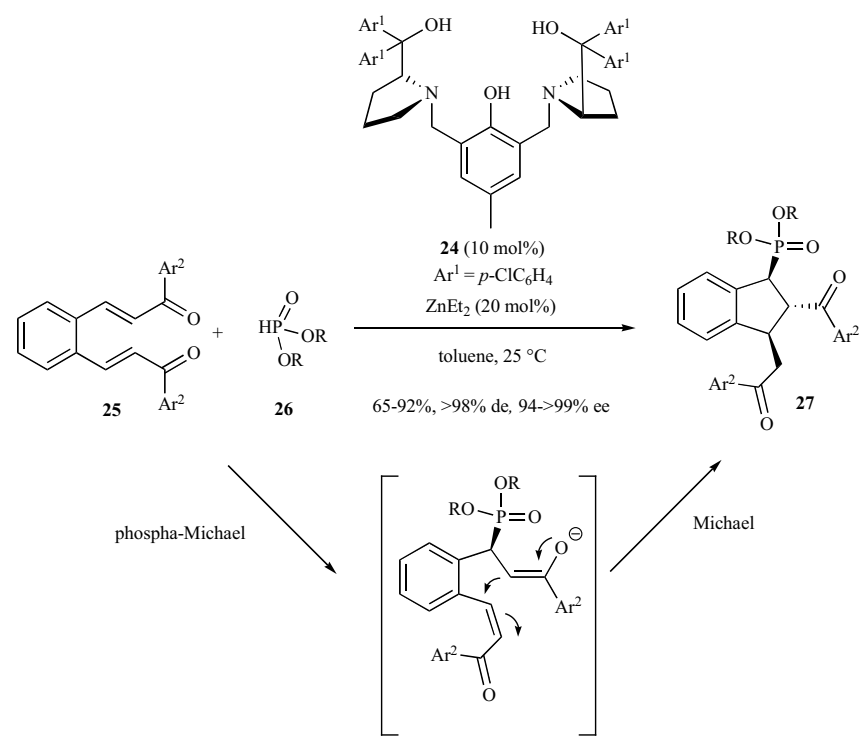

$\mathrm{Ar}^{2}=\mathrm{Ph}, m-\mathrm{FC}_{6} \mathrm{H}_{4}, m-\mathrm{ClC}_{6} \mathrm{H}_{4}, m-\mathrm{BrC}_{6} \mathrm{H}_{4}, m-\mathrm{MeOC}_{6} \mathrm{H}_{4}, p-\mathrm{FC}_{6} \mathrm{H}_{4}, p-\mathrm{ClC}_{6} \mathrm{H}_{4}$ $p$ - $\mathrm{BrC}_{6} \mathrm{H}_{4}, p$ - $\mathrm{Tol}, p$ - $\mathrm{MeOC}_{6} \mathrm{H}_{4}, p-\mathrm{PhC}_{6} \mathrm{H}_{4}, 2$-thienyl $\mathrm{R}=\mathrm{Et}, \mathrm{Me}, i$-Pr, $i$-Bu

Scheme 8. Domino phospha-Michael/Michael reaction of $o$-dienones with dialkyl phosphates.

Another ProPhenol-type ligand, such as 28, was employed in 2019 by Wang et al. to catalyze at only $2 \mathrm{~mol} \%$ of catalyst loading combined with $4 \mathrm{~mol} \%$ of $\mathrm{ZnEt}_{2}$ an enantioselective threecomponent domino reaction of isatins $\mathbf{2 9}$, malononitrile $\mathbf{3 0}$ and $\alpha$ - hydroxy acetophenones 31 [39]. This process, performed at $25{ }^{\circ} \mathrm{C}$ in dichloromethane as a solvent, evolved through a domino Knoevenagel/Michael/cyclization reaction to yield the corresponding chiral 3,3'-dihydrofuran spirooxindoles 32 in both uniformly high yields (86-99\%) and enantioselectivities (82->99\% ee) combined with variable diastereoselectivities (4-98\% de). Generally, the reaction of isatins bearing electron-rich substituents provided slightly higher enantioselectivities than those exhibiting electrondeficient groups. As depicted in Scheme 9, the sequence began with the Knoevenagel condensation of malononitrile 30 to isatin 29 to give product 33. In the presence of the chiral dinuclear zinc catalyst in situ generated from $\mathrm{ZnEt}_{2}$ and ligand 28, $\alpha$-hydroxy acetophenone 31 was deprotonated into a zinc enolate which underwent asymmetric Michael addition to intermediate 33, leading to intermediate 34. The latter was then submitted to cyclization followed by isomerization to afford the final 3,3'-dihydrofuran spirooxindole.

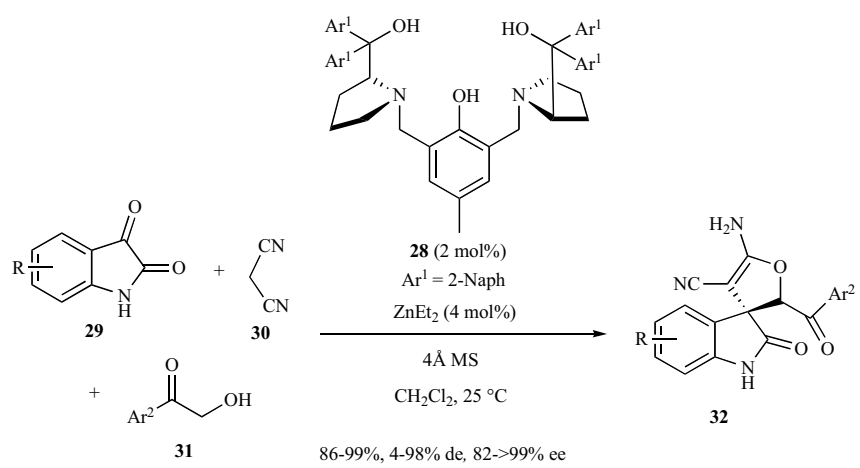

$\mathrm{Ar}^{2}=\mathrm{Ph}, p-\mathrm{FC}_{6} \mathrm{H}_{4}, p-\mathrm{ClC}_{6} \mathrm{H}_{4}, p-\mathrm{BrC}_{6} \mathrm{H}_{4}, p-\mathrm{MeOC}_{6} \mathrm{H}_{4}, p-\mathrm{Tol}, m-\mathrm{ClC}_{6} \mathrm{H}_{4}, m-\mathrm{BrC}_{6} \mathrm{H}_{4}$, $o$ - $\mathrm{MeOC}_{6} \mathrm{H}_{4}, m$-Tol, 2-Naph, 2-thienyl, 2,5-( $\left.\mathrm{MeO}\right)_{2} \mathrm{C}_{6} \mathrm{H}_{3}$

$\mathrm{R}=\mathrm{H}, 5-\mathrm{Me}, 5-\mathrm{MeO}, 5-\mathrm{F}, 5-\mathrm{Cl}, 5-\mathrm{Br}, 6-\mathrm{Br}$

mechanism:<smiles>O=C1Nc2cc[Y]cc2C1=O</smiles><smiles>N#CCCCC#N</smiles>
30<smiles></smiles>

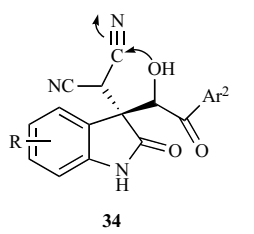<smiles>[Y10]C(C)C1OC(=N)C([Y19])[C@]12C(=O)Nc1ccccc12</smiles>

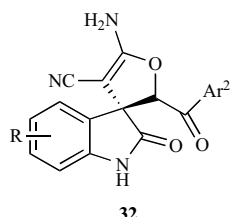

Scheme 9. Three-component domino Knoevenagel/Michael/cyclization reaction of isatins, malononitrile and $\alpha$-hydroxy acetophenones.

Among spirooxindoles, chiral tetrahydrofuran spirooxindoles are especially attractive related to their potent biological activities [40]. In this context, a novel route to these products was developed in 2020 by Hua and Wang on the basis of an enantioselective zinccatalyzed domino Michael/hemiketalization reaction followed by Friedel-Crafts reaction [41]. This sequence involved $\alpha$-hydroxy aryl ketones $\mathbf{3 1}$ and $\beta, \gamma$-unsaturated $\alpha$-ketoamides $\mathbf{3 5}$ as substrates. The domino reaction, performed at $20{ }^{\circ} \mathrm{C}$ in dichloromethane as solvent, was promoted by a chiral dinuclear zinc catalyst in situ 
generated from $20 \mathrm{~mol} \%$ of $\mathrm{ZnEt}_{2}$ and $10 \mathrm{~mol} \%$ of chiral ProPhenol-derived ligand 36. The domino products were not isolated but directly submitted to Friedel-Crafts reaction performed at room temperature by adding trifluoroacetic acid (TFA). The one-pot sequence afforded a wide range of chiral tetrahydrofuran spirooxindoles 37 in high yields (71-90\%), moderate to high diastereoselectivities (50-86\% de) and high to excellent enantioselectivities (75$>99 \%$ ee), as illustrated in Scheme 10. Actually, the enantioselectivities were uniformly excellent $(90->99 \%$ ee) for differently substituted substrates excepted for ortho-methoxy-substituted $\alpha$ hydroxy aryl ketone $\left(\mathrm{Ar}^{2}=o-\mathrm{MeOC}_{6} \mathrm{H}_{4}\right)$, which provided the corresponding product with the lowest ee value $(75 \% \mathrm{ee})$.

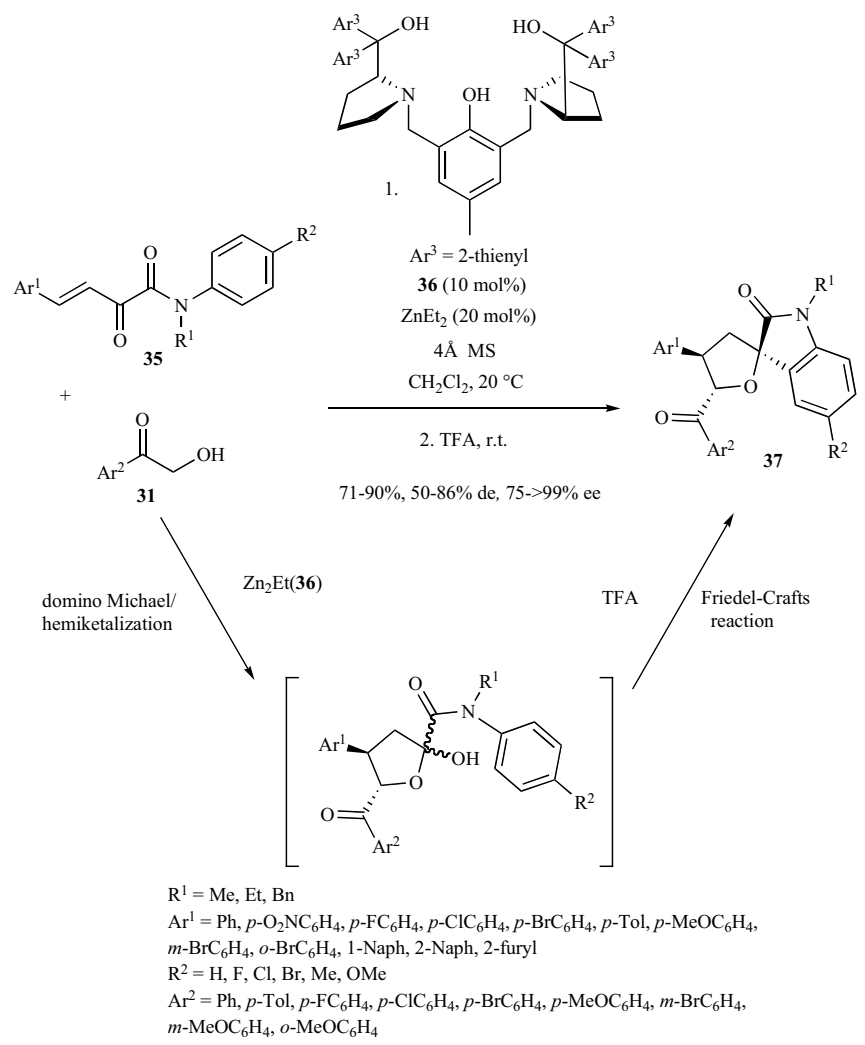

Scheme 10. Domino Michael/hemiketalization reaction of $\alpha$-hydroxy aryl ketones with $\beta, \gamma$-unsaturated $\alpha$-ketoamides followed by Friedel-Crafts reaction.

\subsection{AzePhenol Ligand and Derivatives}

In 2014, Chang and Wang reported the synthesis of a novel chiral semi-aza-crown ligand, namely AzePhenol, exhibiting a more rigid azetidine ring compared with that of pyrrolidine present in ProPhenol ligand [42]. The corresponding chiral dinuclear zinc catalyst $\mathrm{Zn}_{2} \operatorname{Et}((S, S)$-AzePhenol), in situ generated from $2 \mathrm{~mol} \%$ of this ligand and $4 \mathrm{~mol} \%$ of $\mathrm{ZnEt}_{2}$, was employed in 2015 by the same authors to promote an enantioselective domino Michael/hemiketalization reaction (Scheme 11) [43]. It involved arylsubstituted $\beta, \gamma$-unsaturated $\alpha$-ketoesters $\mathbf{1 0}$ and $\alpha$-hydroxyacetophenone $\mathbf{3 1}$ as substrates in dichloromethane as a solvent, leading at $0{ }^{\circ} \mathrm{C}$ to the corresponding chiral 2,2,4,5-tetrasubstituted tetrahydrofurans 38 in good yields (64-90\%), uniformly excellent enantioselectivities $(90-98 \%$ ee) and low to good diastereoselectivities $(26-82 \%$ de). The lowest diastereoselectivities $(26-40 \%$ de) were obtained in the reaction of $\beta, \gamma$-unsaturated $\alpha$-ketoesters with substituents on the phenyl ring at the meta-position. Interestingly, products 38 could be converted under acidic conditions into the corresponding chiral 2,3,5-trisubstituted 2,3-dihydrofurans 39 without loss of enantiopurity.
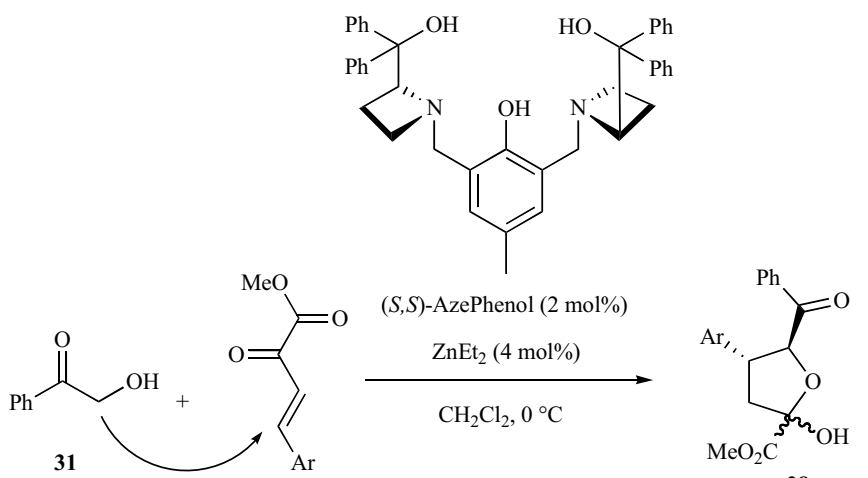

38
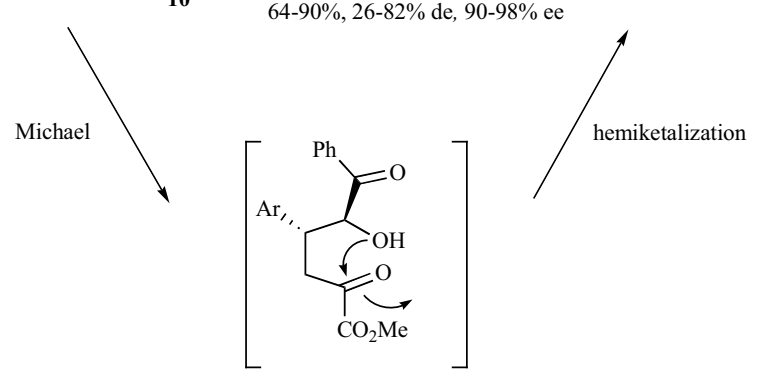

$\mathrm{Ar}=\mathrm{Ph}, p-\mathrm{FC}_{6} \mathrm{H}_{4}, p-\mathrm{ClC}_{6} \mathrm{H}_{4}, p-\mathrm{BrC}_{6} \mathrm{H}_{4}, p-\mathrm{O}_{2} \mathrm{NC}_{6} \mathrm{H}_{4}, p$-Tol, $p-\mathrm{MeOC}_{6} \mathrm{H}_{4}$, $m-\mathrm{ClC}_{6} \mathrm{H}_{4}, m-\mathrm{BrC}_{6} \mathrm{H}_{4}, m-\mathrm{MeOC}_{6} \mathrm{H}_{4}, m-\mathrm{Tol}, 3-\mathrm{Br}-4-\mathrm{ClC}_{6} \mathrm{H}_{3}$<smiles>CC(=O)[C@]1(O)C[C@@H](C)[C@H](C(=O)c2ccccc2)O1</smiles>

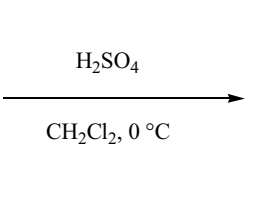

without loss of enantiopurity<smiles></smiles>

39 structure of the in situ generated dinuclear active catalyst:

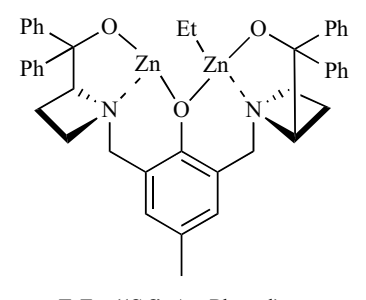

$\mathrm{EtZn}_{2}((S, S)-\mathrm{AzePhenol})$

Scheme 11. Domino Michael/hemiketalization reaction of aryl-substituted $\beta$, $\gamma$-unsaturated $\alpha$-ketoesters with $\alpha$-hydroxyacetophenone.

In 2019 , the same authors developed a novel route to chiral bispirotetrahydrofuran oxindoles based on an enantioselective cascade Michael/hemiketalization/Friedel-Crafts reaction of $\beta, \gamma$ unsaturated $\alpha$-ketoamides $\mathbf{3 5}$ with 2-hydroxy-1-indanones $\mathbf{4 0}$ (Scheme 12) [44]. The sequence began with an asymmetric domino Michael/hemiketalization catalyzed by a chiral dinuclear zinc complex $\mathrm{Zn}_{2} \mathrm{Et}(\mathbf{4 1})$ derived from 4 mol\% of $\mathrm{ZnEt}_{2}$ and $2 \mathrm{~mol} \%$ of chiral AzePhenol-type ligand 41. The reaction, performed in THF at $0{ }^{\circ} \mathrm{C}$, afforded the unstable hemiketal domino product $\mathbf{4 2}$ which was not isolated but directly submitted to TFA which promoted the final 
Friedel-Crafts reaction, leading to expected chiral bispiro[3,2'tetrahydrofuran-5',2"indanone] oxindoles $\mathbf{4 3}$ exhibiting three stereocenters in moderate to high yields $(32-79 \%)$, combined with uniformly high diastereo- $(82->90 \% \mathrm{de})$ and enantioselectivities (87$99 \%$ ee). The scope of the process was wide since a range of either electron-donating or electron-withdrawing substituents $\left(R^{2}, R^{3}\right)$ were tolerated on the phenyl ring of each substrate. However, the reaction of a ketoamide bearing a strong electron-withdrawing group $\left(\mathrm{R}^{2}=\mathrm{NO}_{2}\right)$ led to the corresponding product with a low yield $(32 \%)$ albeit combined with $97 \%$ ee. Moreover, variously $N$ substituted ketoamides all proceeded smoothly.

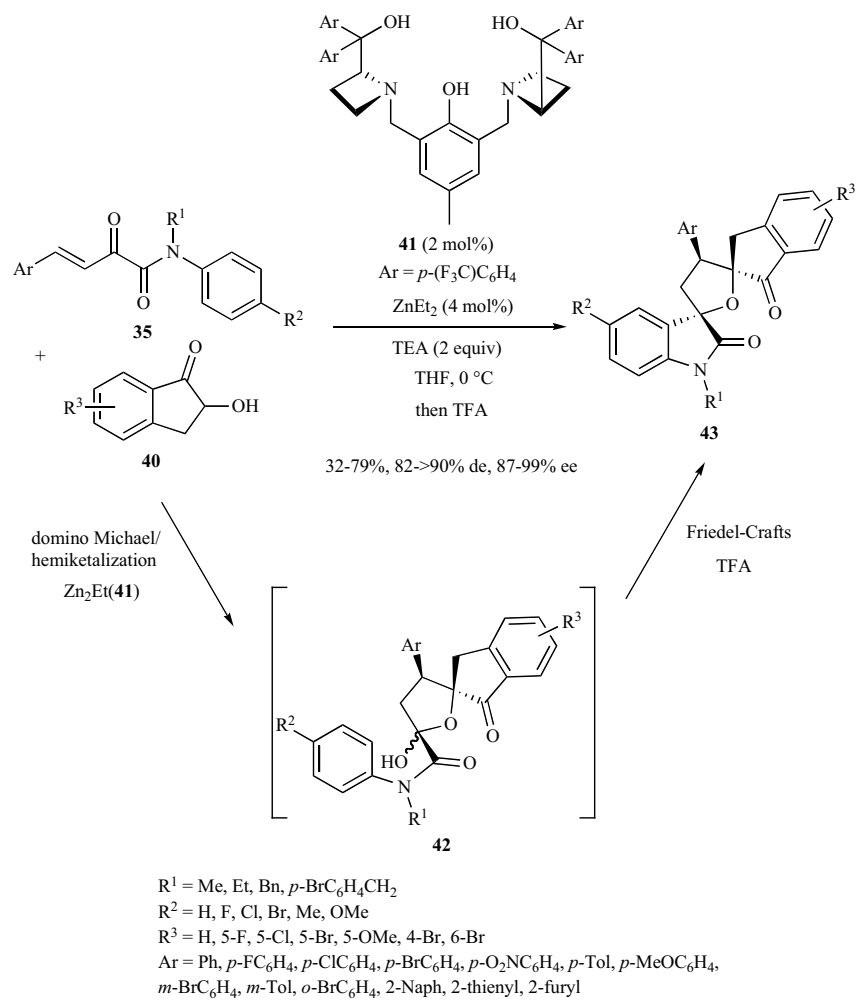

Scheme 12. Domino Michael/hemiketalization reaction of aryl-substituted $\beta, \gamma$-unsaturated $\alpha$-ketoamides and 2-hydroxy-1-indanones followed by Friedel-Crafts reaction.

In the same year, these authors employed the dinuclear zinc complex $\mathrm{Zn}_{2} \operatorname{Et}((S, S)$-AzePhenol), in situ generated from $5 \mathrm{~mol} \%$ of $(S, S)$-AzePhenol and $10 \mathrm{~mol} \%$ of $\mathrm{ZnEt}_{2}$, to catalyze an enantioselective domino Michael/lactonization reaction between 2-hydroxy1 -indanones $\mathbf{4 0}$ and phenyl $\alpha, \beta$-unsaturated esters 3 [45]. Performed at $55{ }^{\circ} \mathrm{C}$ in $\mathrm{THF}$ as a solvent, the process afforded a range of variously substituted chiral spiro[1-indanone-5, $2^{\prime}-\gamma$-butyrolactones] 44 as almost single diastereomers ( $>90 \%$ de) in uniformly high yields $(76-92 \%)$ and remarkable enantioselectivities (95->99\% ee), as presented in Scheme 13.

In the same area, comparable excellent results were reported by the same group in 2020 in a related enantioselective zinc-catalyzed domino Michael/lactonization reaction between $\alpha$-hydroxy indanones 40 and ortho-ester chalcones 45 [46]. In this case, a related chiral AzePhenol derivative 46 was used at $5 \mathrm{~mol} \%$ of catalyst loading as an optimal ligand in combination with $10 \mathrm{~mol} \%$ of $\mathrm{ZnEt}_{2}$. The corresponding in situ generated chiral dinuclear zinc complex $\mathrm{Zn}_{2} \mathrm{Et}(46)$ promoted the domino reaction in $\mathrm{THF}$ at $10{ }^{\circ} \mathrm{C}$, leading to a range of enantio- and diastereomerically pure spiro[indanone-2,3'-isochromane-1-one] derivatives $\mathbf{4 7}$ in good to high yields $(59-92 \%)$ and remarkable diastereo- and enantioselectivities ( $>90 \%$ de, and $96->99 \%$ ee, respectively). As shown in Scheme 14, the electronic nature and position of substituents on the phenyl ring of either $\alpha$-hydroxy indanones or ortho-ester chalcones had little impact on the stereoselectivities of the reaction. This novel methodology allowed simple and direct access to chiral isochromanones, which are potent biologically active products.
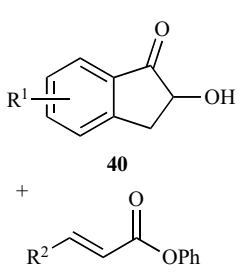<smiles>Cc1cc(CN2CC2)c(O)c(CN2CCC2C(O)(c2ccccc2)c2ccccc2)c1</smiles>

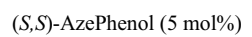
$\mathrm{ZnEt}_{2}(10 \mathrm{~mol} \%)$ $\mathrm{THF}, 55^{\circ} \mathrm{C}$<smiles>[R][X]c1ccc2c(c1)C[C@]1(OC(=O)C[C@H]1[2H])C2=O</smiles>
$44 \quad R^{2}$

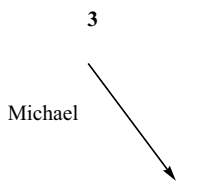

$76-92 \%,>90 \%$ de, $95->99 \%$ ee

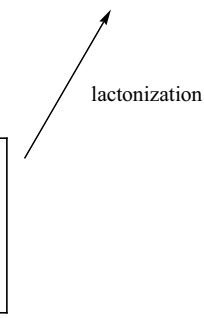

$\mathrm{R}^{1}=\mathrm{H}, 5-\mathrm{F}, 5-\mathrm{Cl}, 5-\mathrm{Br}, 5-\mathrm{OMe}, 4-\mathrm{Br}, 6-\mathrm{Br}$

$\mathrm{R}^{2}=\mathrm{Ph}, p-\mathrm{FC}_{6} \mathrm{H}_{4}, p-\mathrm{ClC}_{6} \mathrm{H}_{4}, p-\mathrm{Tol}, p-\mathrm{MeOC}_{6} \mathrm{H}_{4}, m-\mathrm{ClC}_{6} \mathrm{H}_{4}, m-\mathrm{BrC}_{6} \mathrm{H}_{4}, m-\mathrm{Tol}$, $m-\mathrm{MeOC}_{6} \mathrm{H}_{4}, o-\mathrm{BrC}_{6} \mathrm{H}_{4}, o-\mathrm{MeOC}_{6} \mathrm{H}_{4}, 3-\mathrm{Br}-4-\mathrm{ClC}_{6} \mathrm{H}_{3}, 2-\mathrm{F}-4-\mathrm{BrC}_{6} \mathrm{H}_{3}, 2,4-\mathrm{Cl}_{2} \mathrm{C}_{6} \mathrm{H}_{3}$, 3,4-OCH $\mathrm{OC}_{2} \mathrm{O}-\mathrm{C}_{6} \mathrm{H}_{3}, 1-\mathrm{Naph}, 2$-Naph, 2-thienyl, $\mathrm{H}, \mathrm{Me}$

Scheme 13. Domino Michael/lactonization reaction of $\alpha$-hydroxy-1indanones with phenyl $\alpha, \beta$-unsaturated esters.

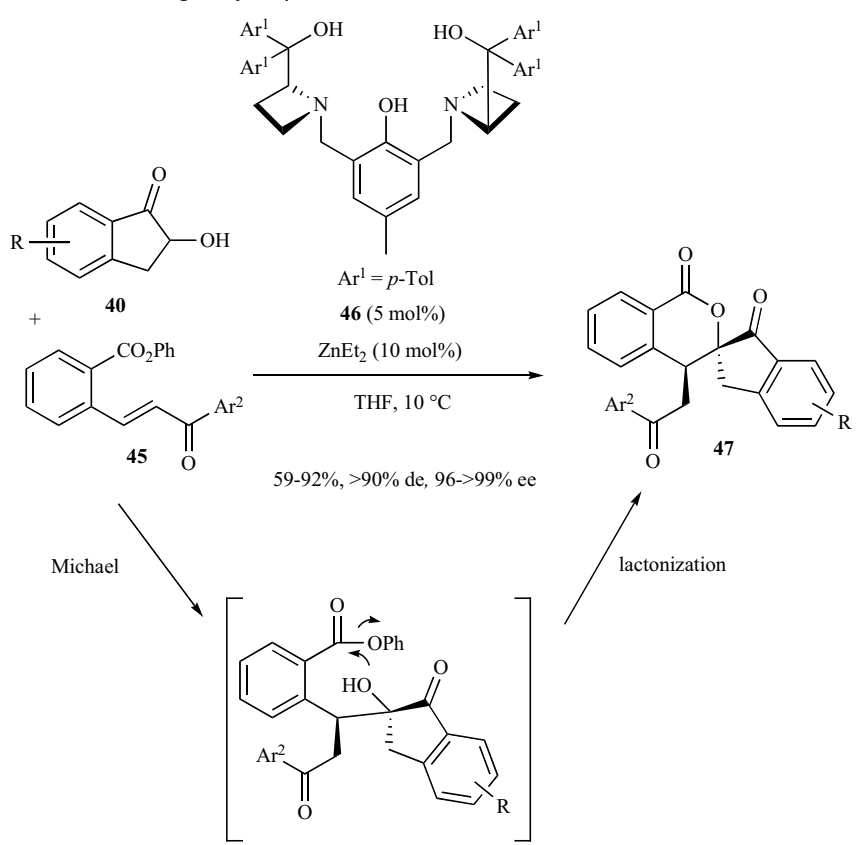

$\mathrm{R}=\mathrm{H}, 5-\mathrm{F}, 5-\mathrm{Cl}, 5-\mathrm{Br}, 5-\mathrm{OMe}, 4-\mathrm{Br}, 6-\mathrm{Br}$

$\mathrm{Ar}^{2}=\mathrm{Ph}, p-\mathrm{BrC}_{6} \mathrm{H}_{4}, p-\mathrm{Tol}, p-\mathrm{FC}_{6} \mathrm{H}_{4}, p-\mathrm{ClC}_{6} \mathrm{H}_{4}, p-\mathrm{MeOC}_{6} \mathrm{H}_{4}, m-\mathrm{FC}_{6} \mathrm{H}_{4}, m-\mathrm{ClC}_{6} \mathrm{H}_{4}$, $m-\mathrm{BrC}_{6} \mathrm{H}_{4}, m-\mathrm{MeOC}_{6} \mathrm{H}_{4}, o-\mathrm{ClC}_{6} \mathrm{H}_{4}, o-\mathrm{BrC}_{6} \mathrm{H}_{4}, o-\mathrm{MeOC}_{6} \mathrm{H}_{4}, 2,4-\mathrm{Cl}_{2} \mathrm{C}_{6} \mathrm{H}_{3}$, 3,4- $\mathrm{Cl}_{2} \mathrm{C}_{6} \mathrm{H}_{3}, 2,4-\mathrm{Cl}_{2}-5-\mathrm{FC}_{6} \mathrm{H}_{2}, 2$-thienyl, 2-Naph

Scheme 14. Domino Michael/lactonization reaction of $\alpha$-hydroxy-1indanones with ortho-ester chalcones. 


\section{3. $\mathrm{C}_{\mathbf{1}}$-Symmetric Aza-Crown Ligands}

In 2019, Wang and Hua developed new access to chiral pyrrolidinyl dispirooxindoles $\mathbf{4 8}$ which constitute potent biologically active products [47]. The methodology was based on a novel asymmetric domino Michael/cyclic ketoimine formation reaction followed by a Friedel-Crafts reaction performed in a single vessel. The sequential reaction occurred at $-45{ }^{\circ} \mathrm{C}$ between 3 -amino oxindole hydrochlorides 49 and aryl-substituted $\beta, \gamma$-unsaturated $\alpha$ ketoamides $\mathbf{3 5}$ in a mixture of acetonitrile and dichloromethane as solvent. Among chiral ligands investigated in this process, $C_{2}$ symmetric $(S, S)$-ProPhenol and AzePhenol derivatives all provided low enantioselectivities $(\leq 33 \%$ ee). In this context, the authors developed nonsymmetrical ligands, such as $C_{1}$-symmetric ligand $\mathbf{5 0}$, with electronically and sterically divergent units. The use of a combination of $10 \mathrm{~mol} \%$ of this ligand with $20 \mathrm{~mol} \%$ of $\mathrm{ZnEt}_{2}$ allowed a range of pyrrolidinyl dispirooxindoles $\mathbf{4 8}$ exhibiting two quaternary stereocenters as single diastereomers $(>90-96 \%$ de) to be synthesized in high yields (66-85\%) and moderate to high enantioselectivities (43-95\% ee), as illustrated in Scheme 15. The presence of various substituents at the phenyl ring of aryl-substituted $\beta, \gamma-$ unsaturated $\alpha$-ketoamides 35 was tolerated. Generally, substrates with electron-donating groups at the para position of the phenyl ring $\left(\mathrm{Ar}^{1}\right)$ provided higher enantioselectivities than those with electron-withdrawing groups. The catalytic system was also compatible with heteroaromatic-substituted $\beta, \gamma$-unsaturated $\alpha$-ketoamides and $\gamma$-naphthyl-substituted substrates.

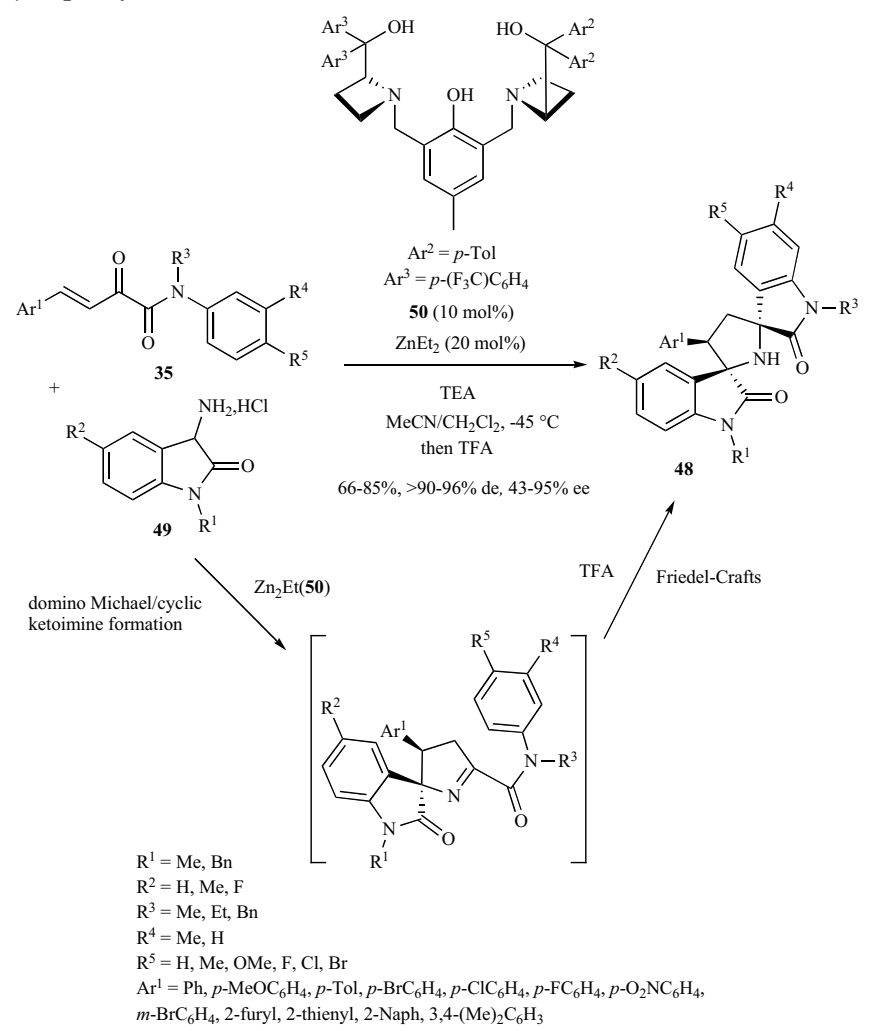

Scheme 15. Domino Michael/ cyclic ketoimine formation reaction of 3amino oxindole hydrochlorides with $\beta, \gamma$-unsaturated $\alpha$-keto amides followed by Friedel-Crafts reaction.

\section{REACTIONS USING BIS(OXAZOLINE) AND BIS(IMIDA- ZOLINE) LIGANDS}

Chiral bis(oxazoline)s [48] have been successfully employed as zinc ligands in various types of asymmetric reactions, including Michael additions [3e], and hydrosilylations of ketones [49], among others. In 2006, this type of ligands was investigated by Takemoto et al. in an enantioselective zinc-catalyzed domino radical addition/cyclization reaction between hydroxamate esters $\mathbf{5 1}$ and alkyl iodides 52 [50]. The reaction evolved through the addition of a radical generated from the alkyl iodide followed by cyclization of the thus formed radical intermediate $\mathbf{5 3}$ into five-membered intermediate 54. Then, the latter led to final lactam 55 through iodide atom-transfer (Scheme 16). Several chiral lactams 55 were synthesized by this methodology as almost single diastereomers $(>96 \%$ de) with good yields (71-78\%) and good enantioselectivities (75$88 \%$ ee). It must be noted that this novel domino reaction presented the disadvantage to require a stoichiometric quantity of catalyst derived from zinc trifluoromethanesulfonate $\left(\mathrm{Zn}(\mathrm{OTf})_{2}\right)$ and bis(oxazoline) 56.

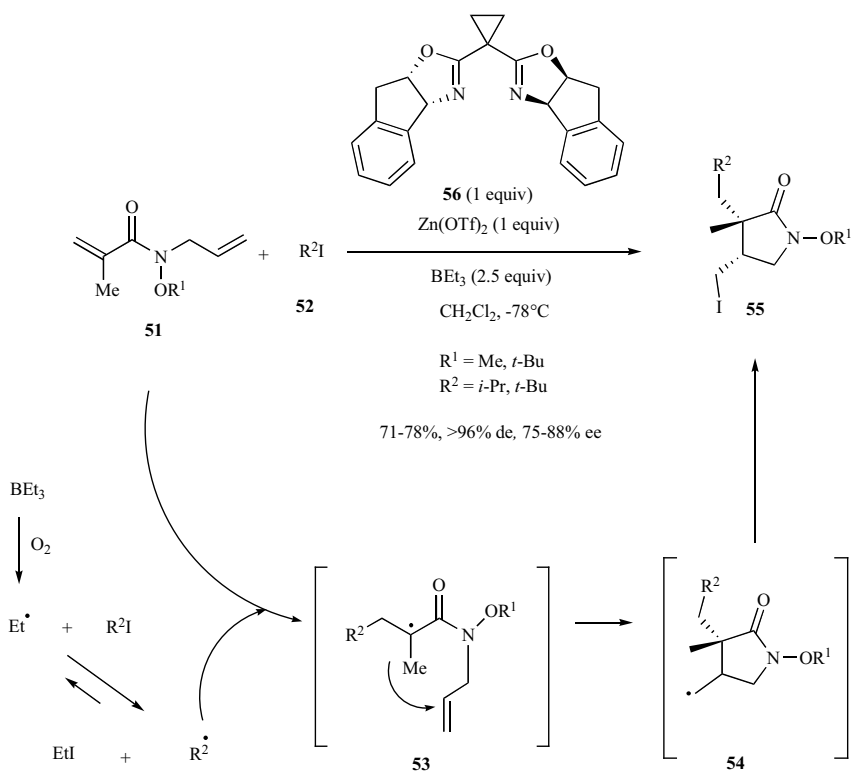

Scheme 16. Domino radical addition/cyclization reaction of hydroxamate esters with alkyl iodides.

Multicatalysis attracts more attention from chemists [51]. As an example, $\mathrm{Hu}$ et al. developed in 2010 an enantioselective threecomponent domino oxonium ylide formation/Michael reaction of $\alpha, \beta$-unsaturated 2-acyl imidazoles 57, diazo compounds 58 and water [52]. As shown in Scheme 17, the process was multicatalyzed by a combination of a chiral zinc complex, in situ generated from $30 \mathrm{~mol} \%$ of $\mathrm{Zn}(\mathrm{OTf})_{2}$ and the same quantity of chiral bis(oxazoline) ligand $\mathbf{5 9}$, and $2 \mathrm{~mol} \%$ of dirhodium tetraacetate $\left(\left[\mathrm{Rh}_{2}(\mathrm{OAc})_{4}\right]\right)$ in dichloromethane as solvent. This cooperative catalysis allowed at $-8{ }^{\circ} \mathrm{C}$ to synthesize a range of chiral $\gamma$ hydroxyketones $\mathbf{6 0}$ bearing two contiguous stereogenic centers, including one quaternary. These products were obtained in good yields $(60-81 \%)$ and diastereoselectivities $(72-98 \%$ de) combined with high enantioselectivities $(85-99 \%$ ee). The rhodium catalyst was supposed to promote the formation of an oxonium ylide from the diazoacetate reagent and water, which was further trapped by the $\alpha, \beta$-unsaturated 2-acyl imidazole activated by the zinc catalyst through a Michael reaction to give the final domino product. It was found that electronic variations on the aromatic substituents of both the imidazoles and the diazoacetates were tolerated.

In 2011, Shibata et al. developed an enantioselective threecomponent Kabachnik-Fields reaction of aldehydes 61, $p$ aminophenol 62 and diarylphosphite 26a catalyzed by a chiral zinc complex derived from $10 \mathrm{~mol} \%$ of bis(imidazoline) ligand $\mathbf{6 3}$ and 
the same quantity of zinc di[bis(trifluoromethylsulfonyl)imide] $\left(\mathrm{Zn}\left(\mathrm{NTf}_{2}\right)_{2}\right)$ [53]. Performed at $-50{ }^{\circ} \mathrm{C}$ in dichloromethane as solvent, the one-pot process afforded a range of chiral $\alpha$ aminophosphonates 64 in excellent yields (86-99\%) and good to high enantioselectivities (61-93\% ee), as presented in Scheme 18. Actually, the reaction of (hetero)aromatic aldehydes all provided high enantioselectivities (82-93\% ee), while the lowest enantioselectivity $(61 \%$ ee) was obtained in the reaction of an aliphatic aldehyde $(\mathrm{R}=\mathrm{Cy})$. In a possible transition state depicted in Scheme 18, the imine in situ generated from aldehyde $\mathbf{6 1}$ and $p$-aminophenol $\mathbf{6 2}$ coordinated to the chiral zinc catalyst in equatorial position by avoiding the steric repulsion from the bis(imidazoline) ligand. The coordination of the oxygen atom in phosphite to zinc and deprotonation of phosphite afforded the corresponding phosphonate, which attacked the imine avoiding steric repulsion with phenyl groups to give the final product.

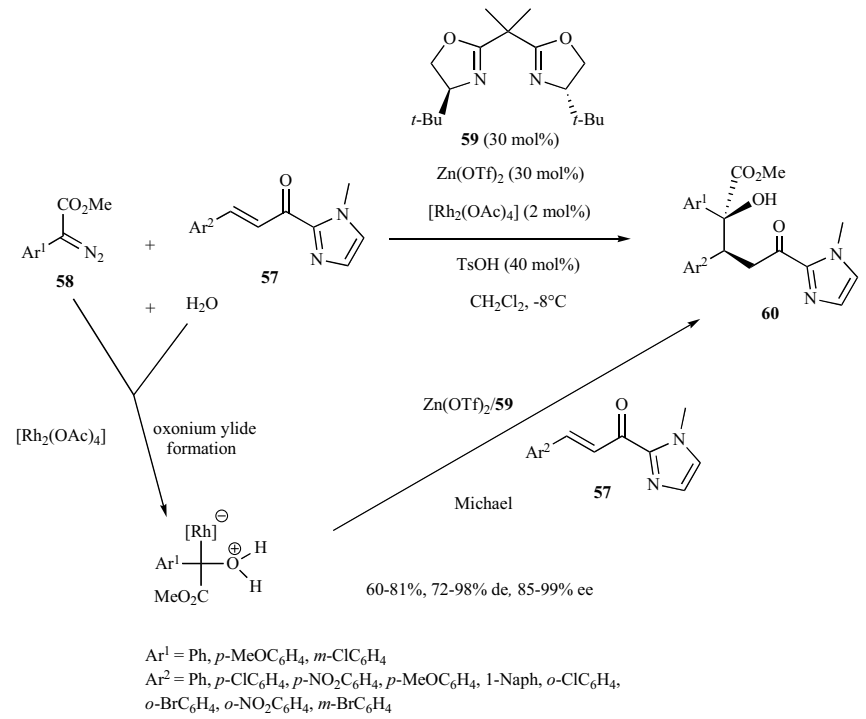

Scheme 17. Three-component domino oxonium ylide formation/Michael reaction of $\alpha, \beta$-unsaturated 2-acyl imidazoles, diazo compounds and water.

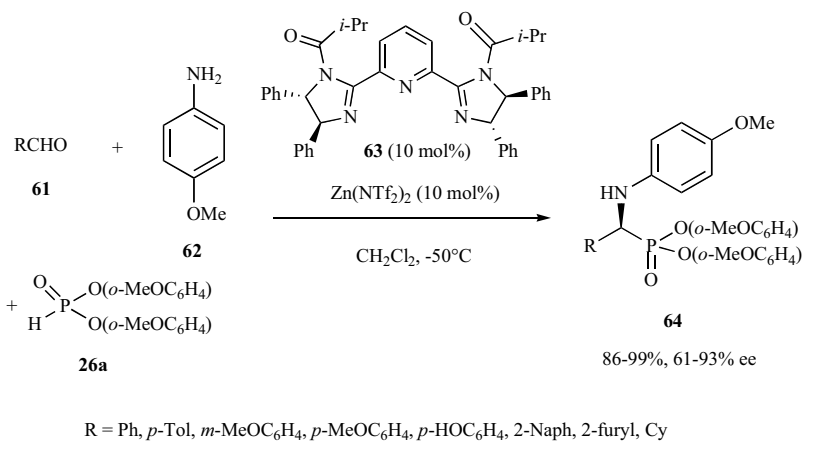

proposed transition state

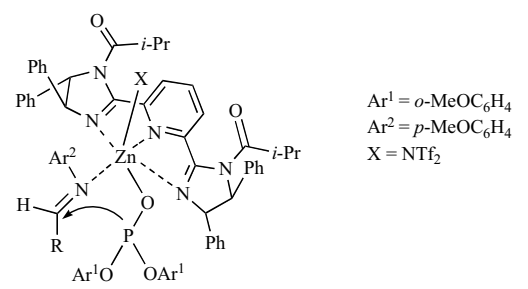

Scheme 18. Three-component Kabachnik-Fields reaction of aldehydes, $p$ aminophenol and a diarylphosphite.
Using chiral bis(oxazoline) ligand $(S, S)$-65 bearing a free $\mathrm{NH}$ group, a novel enantioselective zinc-catalyzed domino Michael/cyclization reaction of 3-nitro- $2 H$-chromenes $66(\mathrm{X}=\mathrm{O})$ with 3 -isothiocyanatooxindoles 67 was developed by Chen and Xiao in 2014 [54]. Indeed, a combination of $11 \mathrm{~mol} \%$ of ligand $(S, S)-\mathbf{6 5}$ with $10 \mathrm{~mol} \%$ of $\mathrm{Zn}(\mathrm{OTf})_{2}$ promoted this domino process at room temperature in toluene as solvent, which led to complex and densely functionalized chiral spirooxindoles $\mathbf{6 8}$ as single diastereomers $(>90 \% \mathrm{de})$ in good to quantitative yields $(72-99 \%)$ and uniformly excellent enantioselectivities $(91->99 \%$ ee), as shown in Scheme 19. The catalyst system was compatible with the presence of both electron-withdrawing and electron-donating substituents $\left(\mathrm{R}^{1}\right)$ at different positions on the aromatic ring of 3-nitro- $2 \mathrm{H}$ chromenes, providing comparable excellent results. Moreover, variously $(N)$-substituted 3-isothiocyanatooxindoles all provided comparable high levels of stereoselectivities. Furthermore, when the oxygen atom of 3-nitro-2H-chromene was replaced by a methylene group $\left(\mathrm{X}=\mathrm{CH}_{2}\right)$, the reaction also proceeded, affording the corresponding product in $95 \%$ yield, $>90 \%$ de and $>99 \%$ ee.

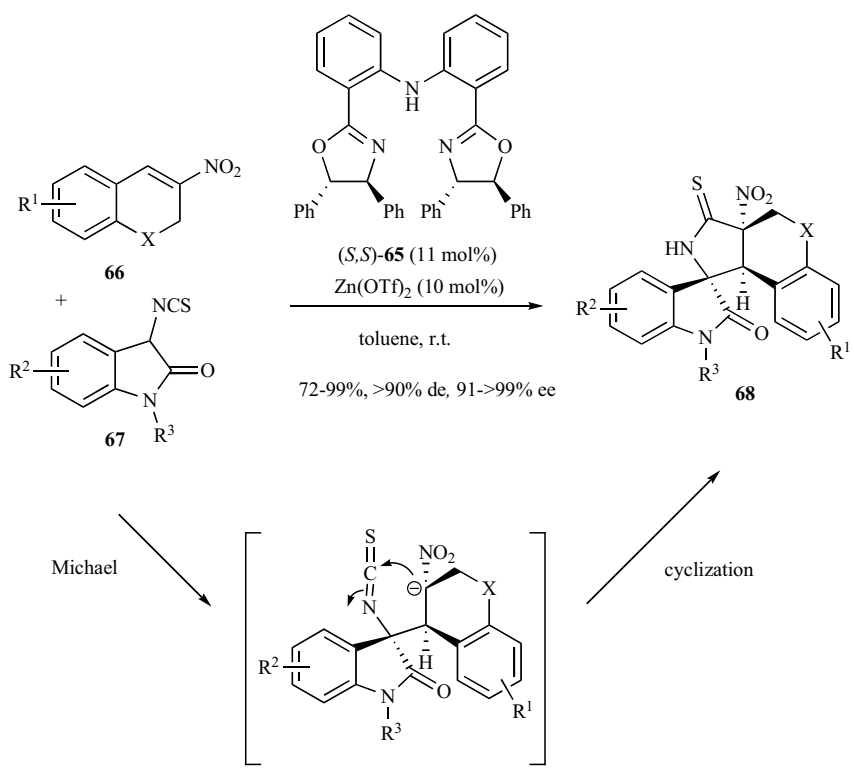

$\mathrm{R}^{1}=\mathrm{H}, 6-\mathrm{F}, 6-\mathrm{Cl}, 6-\mathrm{Br}, 6,8-\mathrm{Br}_{2}, 6-\mathrm{NO}_{2}, 6-\mathrm{Me}, 6-\mathrm{OMe}, 7-\mathrm{OMe}, 8-\mathrm{OMe}$ $\mathrm{R}^{2}=\mathrm{H}, 5-\mathrm{F}, 5-\mathrm{Me}, 5-\mathrm{OMe}$ $\mathrm{R}^{3}=\mathrm{Me}, \mathrm{Bn}$ $\mathrm{X}=\mathrm{O}, \mathrm{CH}_{2}$

Scheme 19. Domino Michael/cyclization reaction of 3-nitro- $2 H$-chromenes $(\mathrm{X}=\mathrm{O})$ with 3-isothiocyanatooxindoles.

In 2015, Xu and Yuan reported a related enantioselective domino Michael/cyclization reaction by using the $(R, R)$-enantiomer of the same ligand 65 [55]. As shown in Scheme 20, the reaction occurred between 3-isothiocyanatooxindoles 67 and 3-nitroindoles 69 in the presence of $11 \mathrm{~mol} \%$ of ligand $(R, R)-65$ and $10 \mathrm{~mol} \%$ of $\mathrm{Zn}(\mathrm{OTf})_{2}$ in toluene at $50^{\circ} \mathrm{C}$, affording the corresponding chiral polycyclic spirooxindoles $\mathbf{7 0}$ in quantitative yields (95-99\%), uniformly impressive enantioselectivities $(91->99 \%$ ee) and generally excellent diastereoselectivities ( $70->98 \%$ de). In most cases of substrates, they were obtained as single diastereomers especially for $\mathrm{N}$ methyl protected 3-isothiocyanatooxindoles. Indeed, the lowest diastereo- $(70 \%$ de) and enantoselectivities $(91 \%$ ee) were observed in the reaction of $N$-phenyl protected 3-isothiocyanatooxindole $\left(\mathrm{R}^{2}\right.$ $=\mathrm{Ph}$ ). Furthermore, the catalytic system was compatible with a range of 3-nitroindoles with no influence of both the electronic nature and the substitution pattern of the substituents $\left(\mathrm{R}^{3}\right)$ on the 
phenyl ring. Moreover, substrates bearing different $N$-substituents $\left(\mathrm{R}^{4}\right)$ provided comparable excellent results.

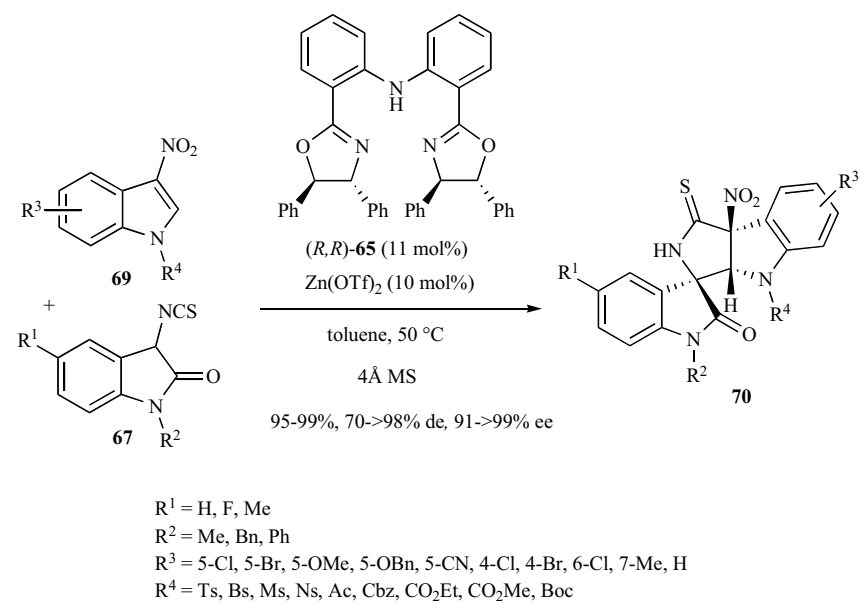

Scheme 20. Domino Michael/cyclization reaction of 3-nitroindoles with3isothiocyanatooxindoles.

In 2018, the same authors developed enantioselective domino Michael/cyclization reaction of 3-isothiocyanatooxindoles 67 with 3-nitrobenzothiophenes 71 [56]. The reaction was promoted at 50 ${ }^{\circ} \mathrm{C}$ in toluene by a chiral zinc catalyst in situ generated from 5 $\mathrm{mol} \%$ of $\mathrm{Zn}(\mathrm{OTf})_{2}$ and $6 \mathrm{~mol} \%$ of chiral bis(oxazoline) ligand 72 . It afforded the corresponding chiral polycyclic spirooxindoles $\mathbf{7 3}$ containing a 2,3-dihydrobenzothiophene motif with excellent yields $(90-99 \%)$, diastereoselectivities (96- $>98 \%$ de) and enantioselectivities (90->99\% ee), as presented in Scheme 21. Different electrondonating and electron-withdrawing substituents on the phenyl ring of either the 3-isothiocyanatooxindole substrate or the 3nitrobenzothiophene were tolerated, providing similar exceptional results whatever their position. Moreover, different alkyl groups on the N1-position of the 3-isothiocyanatooxindole were compatible.<smiles>[R]c1cc([Y1])c2scc([N+](=O)[O-])c2c1</smiles><smiles>c1ccc(Nc2ccccc2C2=NC(c3ccccc3)CC2)cc1</smiles><smiles>[R]c1cc(C)cc2c1N([R])C(=O)C2[N+]([O-])([Na])[Na]</smiles>
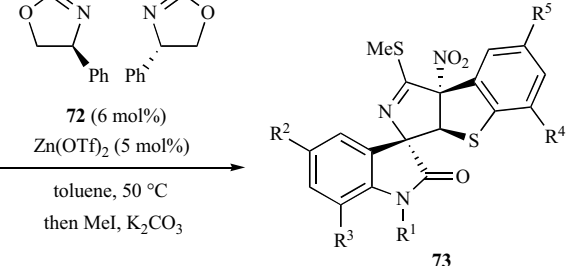

$\mathrm{R}^{1}=\mathrm{Et}, \mathrm{Pr}, \mathrm{Bn}, \mathrm{Ph}, \mathrm{Me}$ $\mathrm{R}^{2}=\mathrm{H}, \mathrm{Me}, \mathrm{OMe}$ $\mathrm{R}^{3}=\mathrm{H}, \mathrm{Me}$ $\mathrm{R}^{4}=\mathrm{H}, \mathrm{Cl}, \mathrm{Me}, \mathrm{Ph}, \mathrm{Br}, \mathrm{F}$

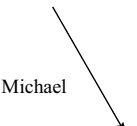

$\mathrm{R}^{5}=\mathrm{H}, \mathrm{Cl}$

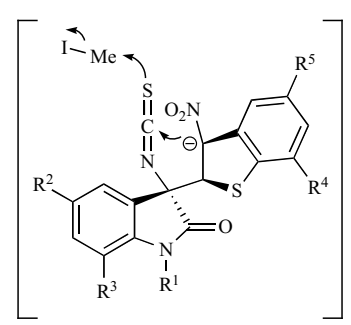

$90-99 \%, 96->98 \%$ de, $90->99 \%$ ee

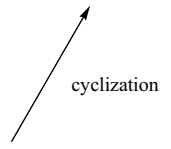

(
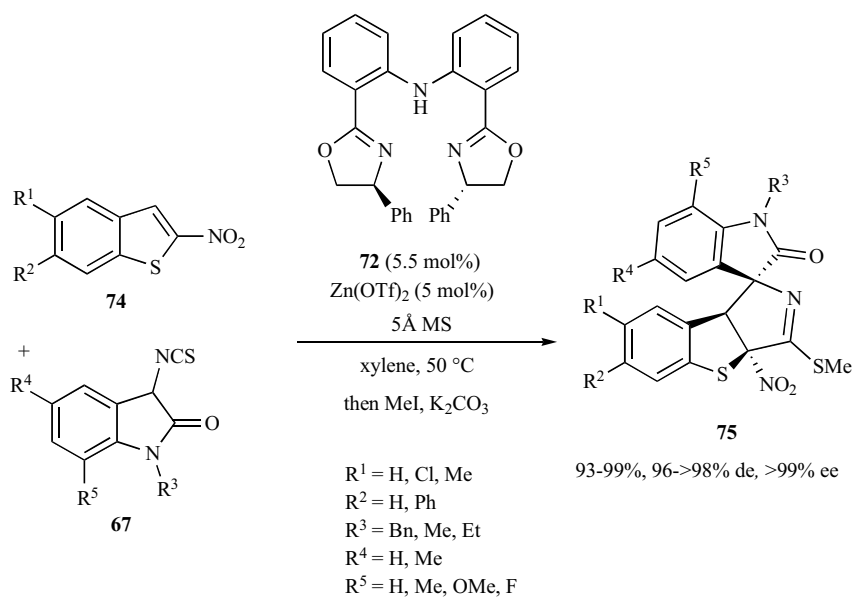
elated enantioselective domino Michael/cyclization reaction of 2-nitrobenzothiophenes 74 with 3-isothiocyanatooxindoles 67 [57]. Again, the results were impressive since the reaction performed in xylene at $50{ }^{\circ} \mathrm{C}$ resulted in the formation of the corresponding complex polycyclic spirooxindoles $\mathbf{7 5}$ as almost single diastereo$(96->98 \%$ de) and enantiomers ( $>99 \%$ ee) in uniformly excellent yields (93-99\%), as illustrated in Scheme 22. The presence of various groups on the aromatic rings was tolerated as well as that of different alkyl $N$-substituents. It must be noted that this work represented the first asymmetric formal dearomative [3+2] cycloaddition of 2-nitroindoles with 3-isothiocyanatooxindoles.

Scheme 22. Domino Michael/cyclization reaction of 2-nitrobenzothiophenes with 3-isothiocyanatooxindoles.

Despite the prevalence of piperidine moieties in drugs, the azaversion of the all-carbon [4+2] cycloaddition is less developed [58]. In this context, Rovis reported in 2015 a rare example of asymmetric synthesis of piperidines which was based on an enantioselective tandem aza-Diels-Alder/reduction reaction of 1 -azadienes 76 with nitroalkenes 77 (Scheme 23) [59]. The chiral catalyst was in situ generated from $20 \mathrm{~mol} \%$ of $\mathrm{Zn}(\mathrm{OTf})_{2}$ and the same quantity of chiral bis(oxazoline) 78 in toluene at $-38{ }^{\circ} \mathrm{C}$, affording a range of chiral piperidines 79 in variable yields (31-87\%) and enantioselectivities (46-92\% ee) as single regio- and diastereomers ( $>90 \%$ de). Actually, due to the instability of the tetrahydropyridine $\mathbf{8 0}$ arisen from the cycloaddition, its enamine functionality was further reduced by treatment with $\mathrm{ZnCl}_{2}$ and sodium cyanoborohydride $\left(\mathrm{NaBH}_{3} \mathrm{CN}\right)$ in methanol to give a more stable 3-nitropiperidine 79. The lowest enantioselectivity $(46 \%$ ee) was obtained in the reaction of an alkyl-substituted azadiene $\left(\mathrm{R}^{1}=i\right.$-Pr). Furthermore, the reaction of a more conjugated azatriene $\left(\mathrm{R}^{1}=(E)-\mathrm{PhCH}=\mathrm{CH}\right)$ required $30 \mathrm{~mol} \%$ of catalyst to provide the corresponding product in $65 \%$ yield and $63 \%$ ee. For all the other differently substituted substrates, enantioselectivities $\geq 69 \%$ ee were obtained.

In 2020, Zhang et al. disclosed an enantioselective domino inverse-electron-demand Diels-Alder/oxidation reaction between indoles 81 and 2-(2-nitrovinyl)-1,4-benzoquinone 82 [60]. It was promoted by a combination of $17 \mathrm{~mol} \%$ of chiral bis(oxazoline) $\mathbf{7 8}$ combined with $10 \mathrm{~mol} \%$ of $\mathrm{Zn}(\mathrm{OTf})_{2}$ at $70{ }^{\circ} \mathrm{C}$ in toluene as solvent, providing the formation of chiral six-membered [2,3]-fused indolines $\mathbf{8 3}$ as single diastereomers in moderate to quantitative yields (34-99\%) and enantioselectivities (37-88\% ee), as presented in Scheme 24. The cycloaddition underwent through the $R e$ face of the 2-(2-nitrovinyl)-1,4-benzoquinone activated by the chiral zinc catalyst which was also $N$-chelated to the indole substrate through $\mathrm{NH}-$
Scheme 21. Domino Michael/cyclization reaction of 3-nitrobenzothiophenes with 3-isothiocyanatooxindoles. 
$\mathrm{p}$ interaction to give Diels-Alder cycloadduct 84. The latter was unstable and subsequently underwent oxidation to give the final product $\mathbf{8 3}$.

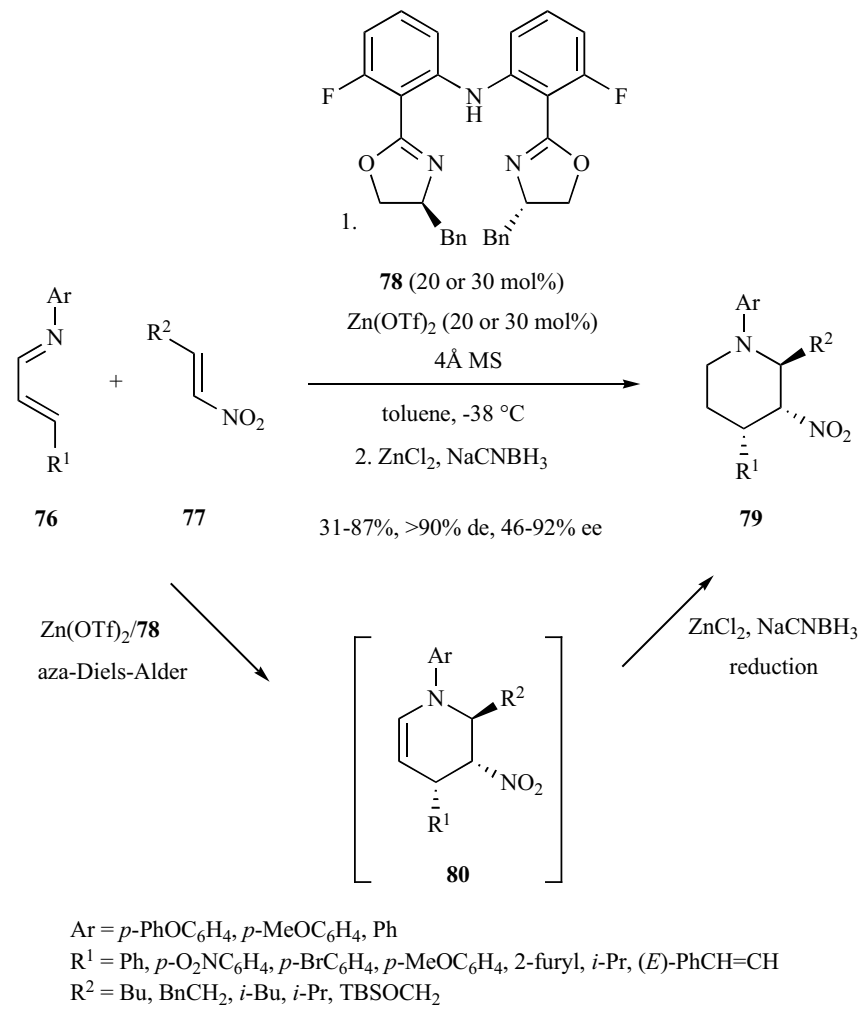

Scheme 23. Tandem aza-Diels-Alder/reduction reaction of 1-azadienes with nitroalkenes.

\section{REACTIONS USING $\boldsymbol{N}, \boldsymbol{N}$ '-DIOXIDE LIGANDS}

Chiral $N, N^{\prime}$-dioxide ligands developed by Feng et al. have been widely employed as ligands in asymmetric catalysis so far [61]. In 2011 , these authors employed a combination of $20 \mathrm{~mol} \%$ of $N, N^{\prime}-$ dioxide ligand $\mathbf{8 5}$ with $10 \mathrm{~mol} \%$ of precatalyst zinc perchlorate hexahydrate $\left(\mathrm{Zn}\left(\mathrm{ClO}_{4}\right)_{2}\left(\mathrm{H}_{2} \mathrm{O}\right)_{6}\right)$ to promote in dichloromethane as solvent an enantioselective three-component reaction between salicylaldehydes 86, malononitrile 30 and indoles 87 [62]. As presented in Scheme 25, the reaction performed at $35{ }^{\circ} \mathrm{C}$ led to a range of chiral 2-amino-4H-chromenes $\mathbf{8 8}$ in good to high yields (37-89\%) and high enantioselectivities $(80-90 \%$ ee). The one-pot process evolved through a domino Knoevenagel/Pinner/Friedel-Crafts reaction. First, a Knoevenagel/Pinner sequence between salicylaldehyde 86 and malononitrile 30 provided an iminochromene intermediate $\mathbf{8 9}$ which subsequently underwent in the presence of indole 87 and the chiral zinc catalyst a Friedel-Crafts reaction to afford the final product. It was found that indoles containing electronwithdrawing groups on the aromatic ring gave higher enantioselectivities than those exhibiting electron-donating groups. The lowest yield (37\%) was observed in the reaction of 4-methoxy-substituted salicylaldehyde. Related to the biologic importance of many natural chromenes, this novel simple route to this type of products is attractive.

In 2019 , the first catalytic enantioselective domino $\alpha$-alkenyl addition/proton shift reactions of silyl enol ethers with cyclic ketimines, such as isatin- and pyrazolinone-derived ketimines, was developed by the same authors in the presence of other $N, N^{\prime}$ dioxide ligands [63]. As depicted in Scheme 26, silyl enol ethers 90 and 91 reacted with isatin-derived ketimine 92 in the presence of
2.5-5 mol\% of a chiral zinc catalyst in situ generated from $\mathrm{Zn}(\mathrm{OTf})_{2}$ and chiral $N, N^{\prime}$-dioxide ligand 93 at $40{ }^{\circ} \mathrm{C}$ to give the corresponding $\beta$-amino silyl enol ethers 94 and $\mathbf{9 5}$, respectively, in excellent enantioselectivities (87-93\% ee) and variable yields (21$90 \%$ ). With the aim of extending the scope of this novel process, the authors investigated the reaction of pyrazolinone-derived ketimines 96 with silyl enol ethers 90 . In this case, the best results were achieved by using a closely related $N, N$ '-dioxide ligand 97 in combination with $\mathrm{Zn}\left(\mathrm{NTf}_{2}\right)_{2}$. Under these conditions, a series of other chiral $\beta$-amino silyl enol ethers 98 were synthesized with both high yields (84-98\%) and enantioselectivities (84-97\% ee).
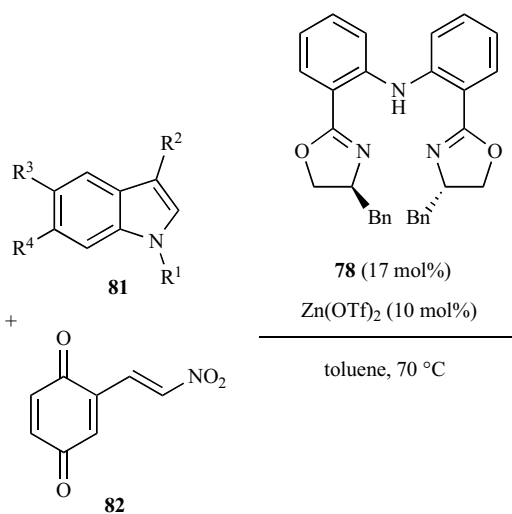

$\mathrm{R}^{1}=\mathrm{Me}$, allyl, $n$ - $\mathrm{Pr}$, 2-propynyl, $\mathrm{Bn}, p-\mathrm{BrC}_{6} \mathrm{H}_{4} \mathrm{CH}_{2}$ $\mathrm{R}^{2}=\mathrm{Me}, \mathrm{MeO}\left(\mathrm{CH}_{2}\right)_{2}$ $\mathrm{R}^{3}=\mathrm{H}, \mathrm{F}, \mathrm{Cl}, \mathrm{Br}, \mathrm{OMe}, \mathrm{OBn}, m-\mathrm{Tol}, p-\mathrm{MeOC}_{6} \mathrm{H}_{4}, p-\mathrm{FC}_{6} \mathrm{H}_{4}, p-\mathrm{F}_{3} \mathrm{CC}_{6} \mathrm{H}_{4}, \mathrm{Me}$ $\mathrm{R}^{4}=\mathrm{H}, \mathrm{F}, \mathrm{Cl}, \mathrm{Br}, \mathrm{OMe}, \mathrm{OBn}, m-\mathrm{Tol}, p-\mathrm{MeOC}_{6} \mathrm{H}_{4}, p-\mathrm{FC}_{6} \mathrm{H}_{4}, p-\mathrm{F}_{3} \mathrm{CC}_{6} \mathrm{H}_{4}, \mathrm{Me}$

mechanism with $\mathrm{R}^{1}=\mathrm{R}^{2}=\mathrm{Me}, \mathrm{R}^{3}=\mathrm{R}^{4}=\mathrm{H}$ :<smiles>Cc1cn(C)c2ccccc12</smiles><smiles>C/C=C/NCC</smiles>

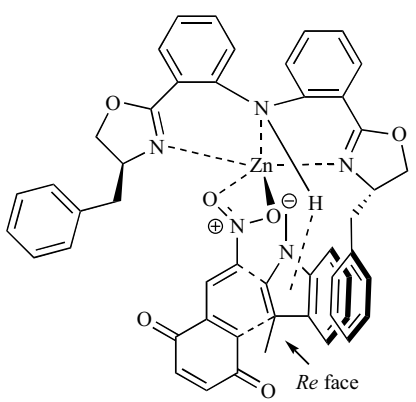

$\longrightarrow$ Diels-Alder

84

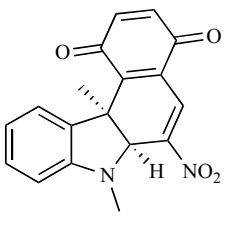

83
Scheme 24. Domino inverse-electron-demand Diels-Alder/oxidation reaction of indoles with 2-(2-nitrovinyl)-1,4-benzoquinone.

In the same year, these authors also reported an enantioselective domino reaction of $\beta, \gamma$-unsaturated $\alpha$-ketoesters 10 with diazoimides 99 promoted at $30^{\circ} \mathrm{C}$ in 1,2-dichloroethane (DCE) as solvent through bimetallic relay catalysis using an achiral rhodium complex, such as dirhodium tetrapivalate $\left(\mathrm{Rh}_{2} \mathrm{Piv}_{4}\right)(0.5 \mathrm{~mol} \%)$, and a chiral zinc catalyst in situ generated from $10 \mathrm{~mol} \%$ of $\mathrm{Zn}(\mathrm{OTf})_{2}$ and $10 \mathrm{~mol} \%$ of chiral $N, N^{\prime}$-dioxide ligand 100 [64]. The rhodium catalyst allowed to generate a carbonyl ylide intermediate from the diazoimide which subsequently reacted through asymmetric [4+3] 


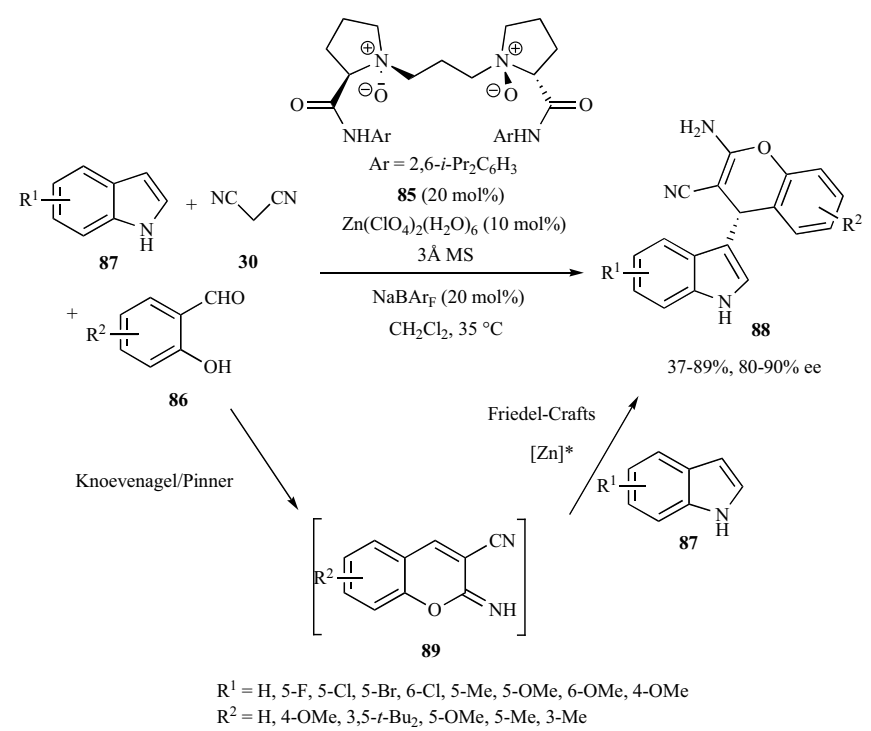

Scheme 25. Three-component domino Knoevenagel/Pinner/Friedel-Crafts reaction of salicylaldehydes, malononitrile and indoles.
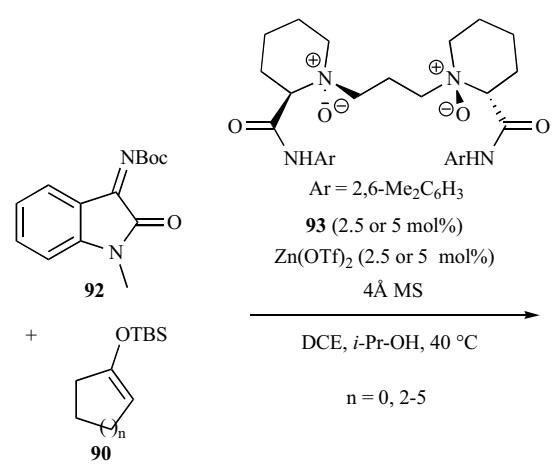

DCE, $i$-Pr-OH, $40{ }^{\circ} \mathrm{C}$

$\mathrm{n}=0,2-5$

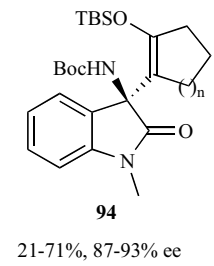<smiles>CN1C(=O)C(=NC(C)(C)C)c2ccccc21</smiles>

same conditions<smiles>[R]c1cc2c(c([R])c1[R])CC=C2O[AsH3]</smiles>
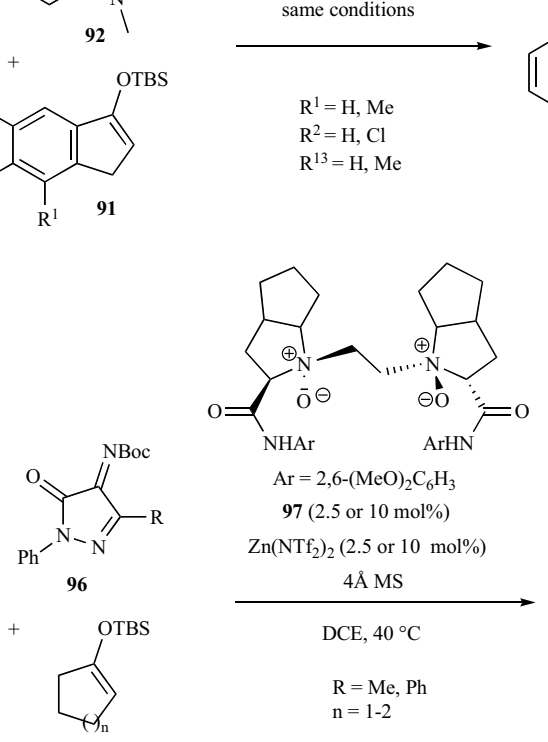

$\mathrm{Ar}=2,6-(\mathrm{MeO})_{2} \mathrm{C}_{6} \mathrm{H}_{3}$

$97(2.5$ or $10 \mathrm{~mol} \%)$

$\mathrm{Zn}\left(\mathrm{NTf}_{2}\right)_{2}(2.5$ or $10 \mathrm{~mol} \%)$

$4 \AA \mathrm{MS}$

DCE, $40{ }^{\circ} \mathrm{C}$

$\mathrm{R}=\mathrm{Me}, \mathrm{Ph}$

$\mathrm{n}=1-2$

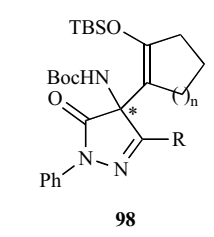

90

Scheme 26. Domino $\alpha$-alkenyl addition/proton shift reactions of silyl enol ethers with isatin- and pyrazolinone-derived ketimines. cycloaddition with the $\beta, \gamma$-unsaturated $\alpha$-ketoester catalyzed by the chiral zinc complex. As illustrated in Scheme 27, this domino carbonyl imide formation/[4+3] cycloaddition reaction resulted in the formation of a range of chiral oxa-bridged oxazocines 101 as almost single exo-diastereomers ( $>90 \% \mathrm{de}$ ) in good to high yields $(51-90 \%)$ and uniformly high enantioselectivities (85-99\% ee). The catalyst system was compatible with various (hetero)arylsubstituted $\beta, \gamma$-unsaturated $\alpha$-ketoesters 10, bearing either electronwithdrawing or electron-donating substituents at different positions of the phenyl group. Heteroaromatic-substituted substrates were also compatible, as well as various alkyl ester groups $\left(\mathrm{R}^{1}\right)$. Furthermore, variously $(N)$-substituted diazoimides reacted smoothly. The mechanism proposed in Scheme 27 shows the formation of rhodium carbene species $\mathbf{H}$ from diazoimide 99 and $\mathrm{Rh}_{2} \mathrm{Piv}_{4}$. Then, an intramolecular carbonyl attack on the rhodium carbene occurred to form intermediate $\mathbf{I}$. The latter reacted with the $\beta, \gamma$-unsaturated $\alpha$-ketoester 10 activated by the chiral zinc catalyst through a [4+3]cycloaddition to provide the final product.

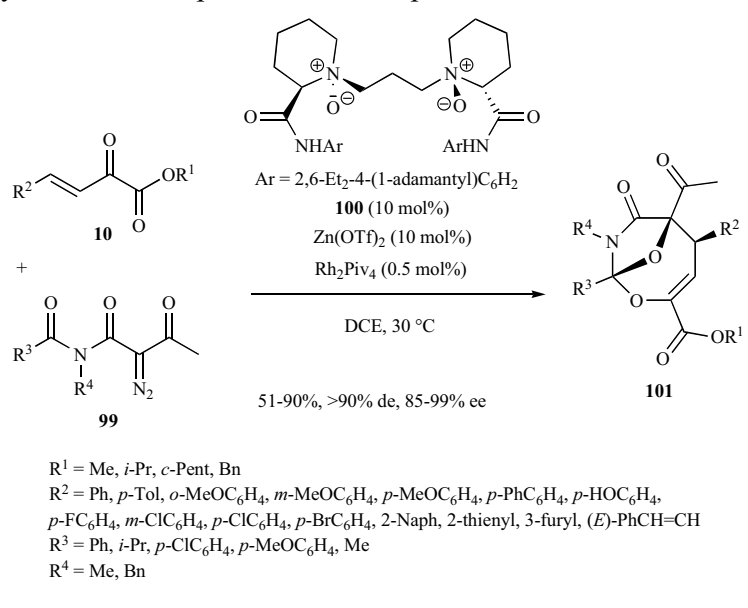

mechanism:

Scheme 27. Domino carbonylimide formation/[4+3] cycloaddition reaction of $\beta, \gamma$-unsaturated $\alpha$-ketoesters with diazoimides.

\section{REACTIONS USING BINOL-DERIVED LIGANDS}

In 2009, Xu et al. reported an asymmetric zinc-promoted threecomponent reaction occurring between $N$-tosylaldimines 102 and two different terminal alkynes $\mathbf{1 0 3}$ and $\mathbf{1 0 4}$ [65]. The process was mediated by two equivalents of dimethyl zinc combined with 20 mol\% of BINOL-derived ligand $\mathbf{1 0 5}$ in toluene at room temperature to reflux. It resulted in the formation of chiral propargylic amines 
106 in moderate to high yields (51-92\%) and uniformly high enantioselectivities (84-99\% ee), as shown in Scheme 28. The mechanism involved the formation of alkynylzinc $\mathbf{J}$ which added to $N$ tosylaldimine $\mathbf{1 0 2}$ to give $\pi$-complex intermediate $\mathbf{K}$. Then, the latter underwent an attack by another alkynylzinc to form cyclic intermediate $\mathbf{L}$. The carbon-zinc bond in $\mathbf{L}$ could be subsequently cleaved by an excess of alkyne to give intermediate $\mathbf{M}$. Then, the acidic hydrolysis of $\mathbf{M}$ led to the final product.
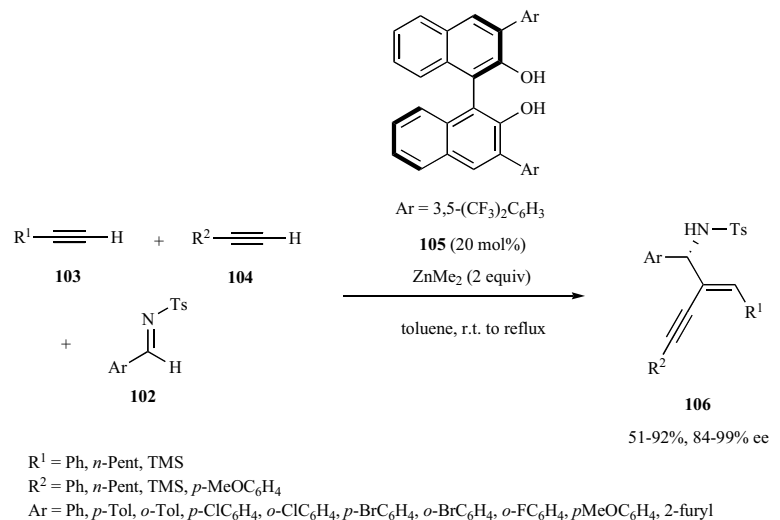

proposed mechanism (with $\mathrm{R}^{1}=\mathrm{R}^{2}=\mathrm{Ph}$ ):

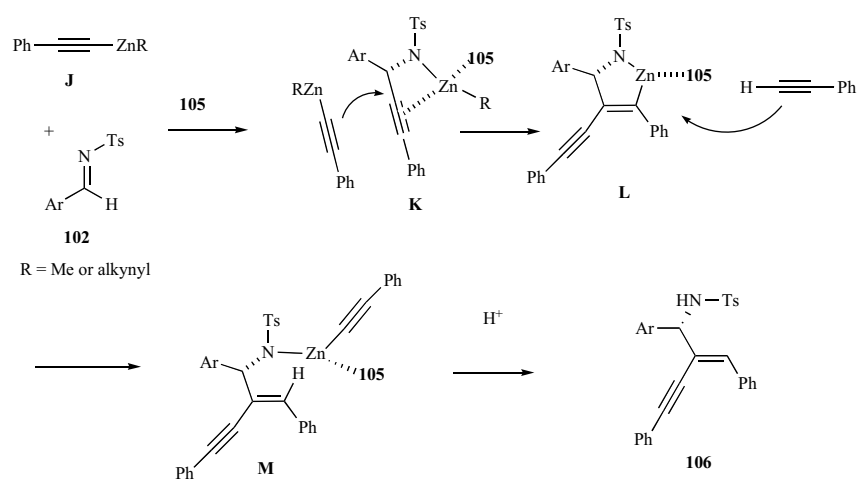

Scheme 28. Three-component reaction of $N$-tosylaldimines with two different terminal alkynes.

In 2015, Ishihara et al. reported the first asymmetric domino Diels-Alder/lactonization reaction of 2,4-dienols 107 with acrylates 108 performed in the presence of a catalyst system composed of 20 mol\% of $(R)-\mathrm{H}_{8}-\mathrm{BINOL}, 20 \mathrm{~mol} \%$ of $\mathrm{ZnMe}_{2}$ and $20 \mathrm{~mol} \%$ of methyl magnesium bromide [66]. This bimetallic catalyst allowed at room temperature in dichloromethane as a solvent the formation of chiral bicyclic $\gamma$-lactones $\mathbf{1 0 9}$ as single diastereomers in low to quantitative yields (16->99\%) and moderate to excellent enantioselectivities (41-97\% ee), as shown in Scheme 29.

\section{REACTIONS USING 1,2-DIAMINE LIGANDS}

In 2015, Song et al. demonstrated that chiral 1,2-amino phosphoramide ligand $\mathbf{1 1 0}$ was efficient in both the asymmetric $\beta-\mathrm{H}$ transfer reduction of aryl $\alpha$-trifluoromethylketones 111,112 and enantioselective addition of $\mathrm{ZnEt}_{2}$ of aromatic aldehydes performed in one-pot under the same reaction conditions [67]. As shown in Scheme 30, the corresponding chiral fluorinated diols 113,114 were obtained from the domino transfer reduction/ethylation reaction performed in toluene at $-20{ }^{\circ} \mathrm{C}$ in the presence of $30 \mathrm{~mol} \%$ of ligand 110 in high yields (86-90\%) with excellent enantioselectivities $(92-97 \%$ ee) albeit combined with moderate diastereoselectivities $(40-42 \%$ de).
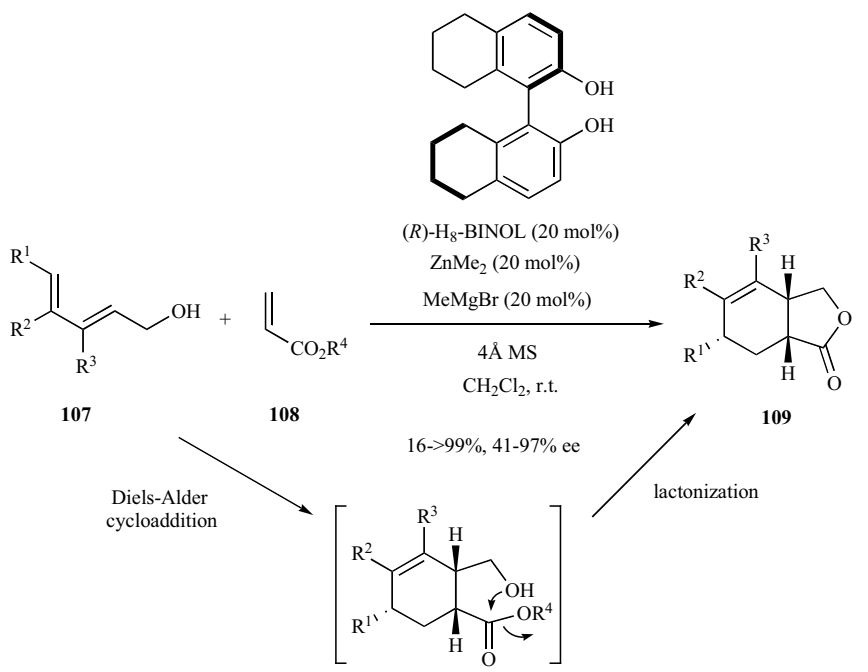

$\mathrm{R}^{1}=\mathrm{H}, \mathrm{Me}$

$\mathrm{R}^{2}=\mathrm{Me}, \mathrm{H}, \mathrm{BnO}\left(\mathrm{CH}_{2}\right)_{2}$

$\mathrm{R}^{3}=\mathrm{Me}, \mathrm{H}$

$\mathrm{R}^{4}=\mathrm{Me}$, Et, $i$-Bu, 1-Naph, 2-Naph

Scheme 29. Domino Diels-Alder/lactonization reaction of 2,4-dienols with acrylates.

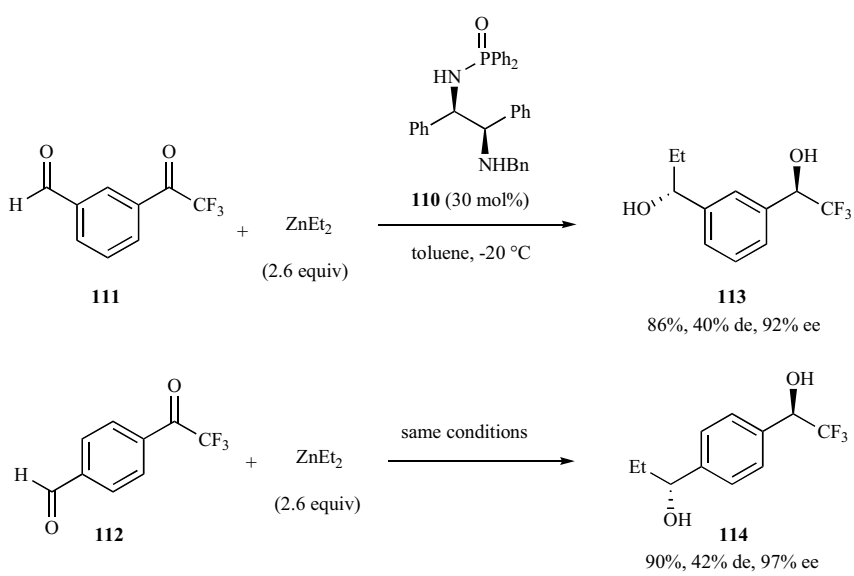

Scheme 30. Domino transfer reduction/ethylation reactions of aryl $\alpha$ trifluoromethylketones with $\mathrm{ZnEt}_{2}$

In 2020, a novel asymmetric synthesis of $\beta$-hydroxy esters was disclosed by Mlynarski et al. through the first enantioselective three-component domino reductive Michael/aldol reaction of acrylates 108, (hetero)aromatic ketones 115 and triethoxysilane $\left((\mathrm{EtO})_{3} \mathrm{SiH}\right)$ using zinc acetate as cheap precatalyst [68]. Among chiral ligands based on $(R, R)$-diphenylethylenediamine, diamine 116 was selected as optimal ligand to promote this reaction at 15 mol\% of catalyst loading in $m$-xylene as a solvent. As illustrated in Scheme 31, a series of chiral $\beta$-hydroxy esters 117 were generated at $-30{ }^{\circ} \mathrm{C}$ with moderate to high yields $(50-90 \%)$ and enantioselectivities $(51-91 \%$ ee). However, the diastereoselectivity of the reaction was found low (4-36\% de) and substrate-dependent.

\section{REACTIONS USING OTHER LIGANDS}

In 2007, Bolm et al. disclosed an asymmetric synthesis of $N$ aryl propargylic amines based on an enantioselective threecomponent reaction of aldehydes 61, terminal alkynes $\mathbf{1 0 3}$ and $o$ methoxyaniline 118 (Scheme 32) [69]. This reaction was mediated 
at room temperature in dichloromethane as solvent by four equivalents of $\mathrm{ZnMe}_{2}$ in the presence of $4 \mathrm{~mol} \%$ of chiral $\beta$-amino alcohol ligand 119 derived from norephedrine. It evolved by forming an imine from aldehyde 61 and $o$-methoxyaniline 118, which was then submitted to alkynylation to give the corresponding domino imine formation/alkynylation product $\mathbf{1 2 0}$ in both variable yields (24$85 \%)$ and enantioselectivities (13-97\% ee). Homogeneously good to high enantioselectivities $(68-97 \%$ ee) were obtained in the reaction of phenylacetylene, whereas much lower enantioselectivities (13-53\% ee) were observed with other alkynes. Moreover, a range of aromatic, heteroaromatic and also aliphatic aldehydes provided, by reaction with $o$-anisidine and phenylacetylene, moderate to high enantioselectivities (68-97\% ee).

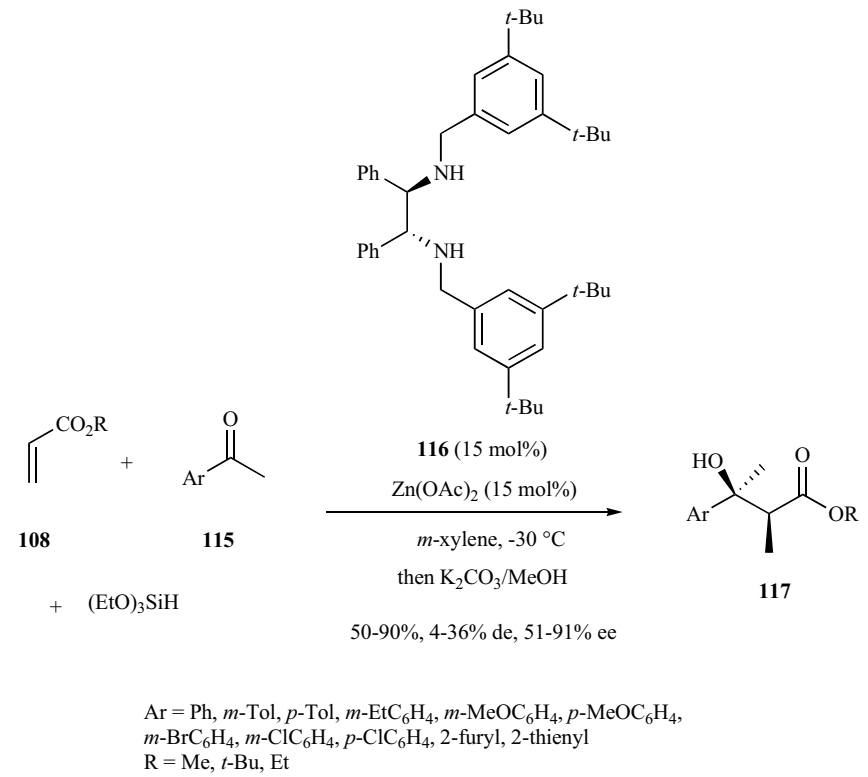

Scheme 31. Three-component domino reductive Michael/aldol reaction of acrylates, aromatic ketones and $(\mathrm{EtO})_{3} \mathrm{SiH}$.

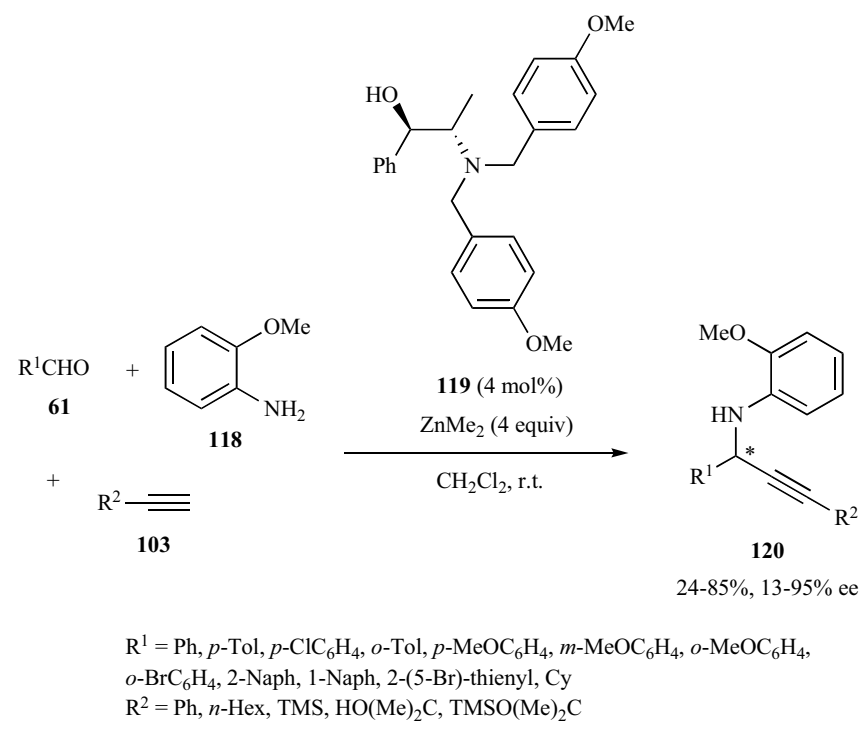

Scheme 32. Three-component domino imine formation/alkynylation reaction of aldehydes, terminal alkynes and $o$-methoxyaniline.

In 2017, Nakamura et al. investigated for the first time the ringopening reaction of protected aziridines $\mathbf{1 2 1}$ with malononitrile $\mathbf{3 0}$ using 12-24 mol\% of a cinchona alkaloid zinc catalyst derived from ligand 122 and $\mathrm{ZnEt}_{2}(10-20 \mathrm{~mol} \%)$ [70]. As illustrated in Scheme
33, acyclic aziridines $\mathbf{1 2 1}$ reacted with malononitrile $\mathbf{3 0}$ to give the corresponding ring-opened products $\mathbf{1 2 3}$ which subsequently underwent an intramolecular nucleophilic addition of the amide nitrogen to the cyano group to provide chiral 2,3-dihydro-1H-pyrrole products 124 in excellent enantioselectivities (90-94\% ee) and good yields $(64-75 \%)$.

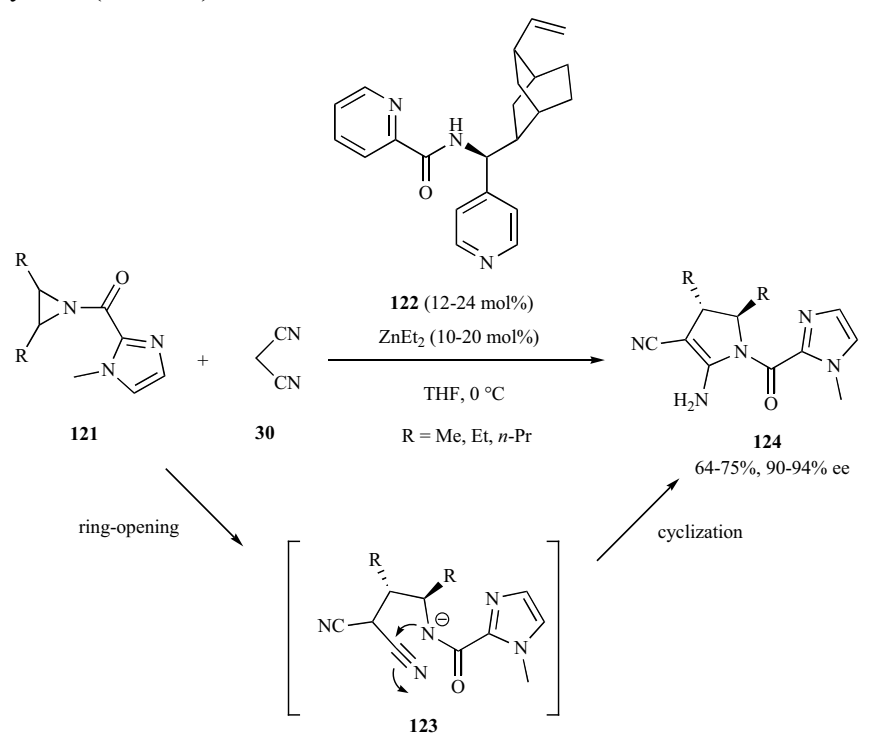

Scheme 33. Domino ring-opening/cyclization reaction of aziridines with malononitrile.

In 2019, a bimetallic rhodium/zinc catalysis was employed by Shao et al. to promote the first enantioselective domino ringopening/cyclopropanation reaction of oxabenzonorbornadienes $\mathbf{1 2 5}$ with phosphorus ylides 126 [71]. The dual catalysis involved a combination of $5 \mathrm{~mol} \%$ of bis(1,5-cyclooctadiene)rhodium(I) tetrafluoroborate $\left(\mathrm{Rh}(\operatorname{cod})_{2} \mathrm{BF}_{4}\right), 50 \mathrm{~mol} \%$ of $\mathrm{Zn}(\mathrm{OTf})_{2}$ and $5.5 \mathrm{~mol} \%$ of chiral biphosphine ligand 127. The reaction allowed a range of chiral benzonorcaradienes $\mathbf{1 2 8}$ to be synthesized as single diastereomers ( $>99 \%$ de) in good to quantitative yields (56-99\%) and high enantioselectivities (86-99\% ee), as illustrated in Scheme 34.

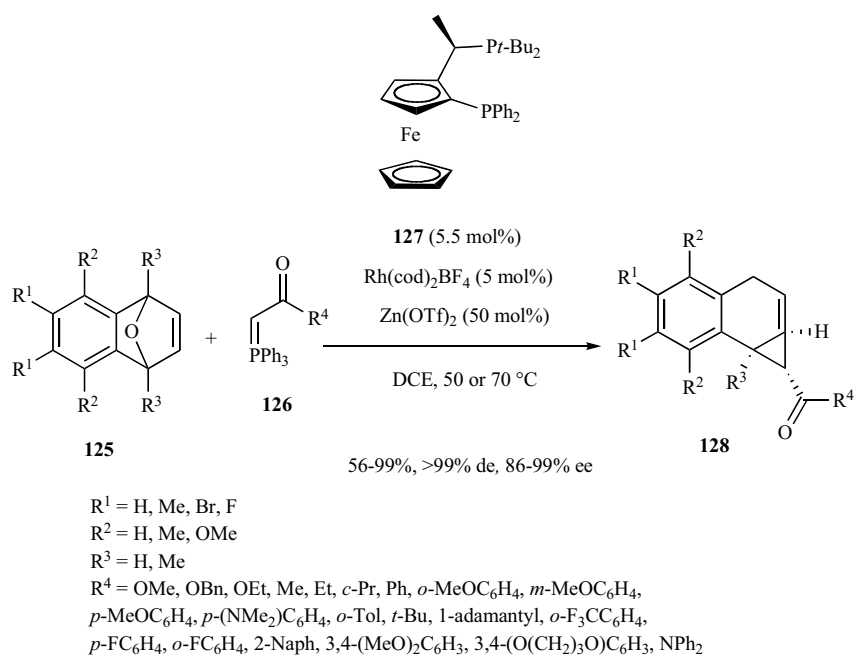

Scheme 34. Domino ring-opening/cyclopropanation reaction of oxabenzonorbornadienes with phosphorus ylides.

In 2020, Fang and Ding developed an enantioselective domino alkynylation/cyclization reaction of alkynyl 1,2-diketones 129 with alkynes 104 catalyzed by a combination of $20 \mathrm{~mol} \%$ of $\mathrm{Zn}(\mathrm{OTf})_{2}$ and $20 \mathrm{~mol} \%$ of chiral amino alcohol ligand $\mathbf{1 3 0}$ at room tempera- 
ture (Scheme 35) [72]. The reaction was performed at $40{ }^{\circ} \mathrm{C}$ in the presence of triethylamine (TEA) as the base, resulting in the formation of biologically important chiral 3(2H)-furanones $\mathbf{1 3 1}$ in moderate to good yields (41-81\%) and uniformly high enantioselectivities (81-99\% ee). It evolved through the mechanism depicted in Scheme 35, involving the nucleophilic addition of TEA to the alkyne unit of the alkynylation product $\mathbf{1 3 2}$ to give allenic intermediate 133. Then, the latter underwent a proton transfer to provide intermediate 134, which cyclized into the final domino product $\mathbf{1 3 1}$.
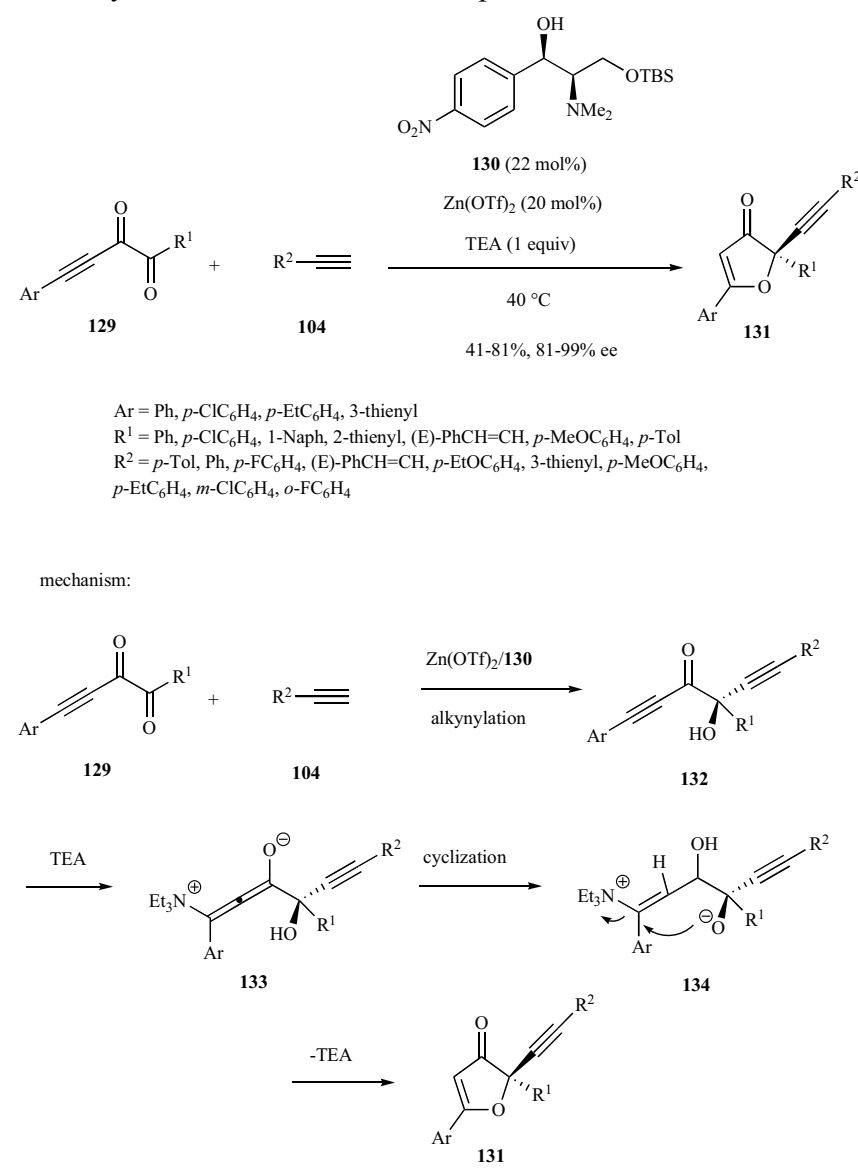

Scheme 35. Domino alkynylation/cyclization reaction of alkynyl 1,2diketones with alkynes.

\section{CONCLUSION}

As an abundant, inexpensive and less toxic metal, zinc has gained significant importance in green catalysis. While underdeveloped for a long time, zinc catalysts are more and more applied to promote economic and ecologic transformations. Especially, a spectacular development of highly enantioselective zinc-catalyzed onepot reactions has emerged. This review highlights for the first time the developments in enantioselective domino and tandem reactions promoted by chiral zinc catalysts derived from various types of ligands, such as semi-aza-crown ligands, bis(oxazoline)s, bis(imidazoline)s, $N, N$ '-dioxides, BINOL derivatives, 1,2-diamines, amino alcohols, among others. It shows that zinc catalysis suits the growing demand for greener processes and offers the real opportunity to replace other toxic and expensive metals in the near future. It demonstrates that zinc brings a novel potential for green catalysis, especially when combined with efficient sophisticated asymmetric one-pot processes and that this original area is growing very rapidly. Indeed, this field is in full bloom, allowing one-pot access to many types of complex functionalized chiral molecules from simple starting materials by using environmentally benign catalysts, and will undoubtedly continue to be expanded in the future with the discovery of novel catalysts. Even if remarkable results have been described, challenges remain, such as the application of these processes in the total synthesis of important biologically active and natural products, as well as the involvement of zinc in even more complicated multicatalyzed processes.

\section{LIST OF ABBREVIATIONS}

$\begin{array}{ll}\text { Ar } & =\text { Aryl } \\ \text { BArF } & =\text { Tetrakis[3,5-bis(trifluoromethyl)phenyl]borate } \\ \text { BINOL } & =1,1 \text { '-bi-2-naphthol } \\ \text { Bn } & =\text { Benzyl } \\ \text { Boc } & =\text { tert-butoxycarbonyl } \\ \text { Bs } & =p \text {-bromobenzenesulfonyl (brosyl) } \\ \text { Cbz } & =\text { Benzyloxycarbonyl } \\ \text { cod } & =\text { Cyclooctadiene } \\ \text { Cy } & =\text { Cyclohexyl } \\ \text { DCE } & =1,2 \text {-dichloroethane } \\ \text { de } & =\text { Diastereomeric excess } \\ \text { ee } & =\text { Enantiomeric excess } \\ \text { Hex } & =\text { Hexyl } \\ \text { Ms } & =\text { Mesityl } \\ \text { MOM } & =\text { Methoxymethyl } \\ \text { MS } & =\text { Molecular sieves } \\ \text { Naph } & =\text { Naphthyl } \\ \text { Ns } & =\text { Nosyl (4-nitrobenzene sulfonyl) } \\ \text { Pent } & =\text { Pentyl } \\ \text { PG } & =\text { Protecting group } \\ \text { Piv } & =\text { Pivalate } \\ \text { PMB } & =\text { para-methoxybenzyl } \\ \text { r.t. } & =\text { Room temperature } \\ \text { TBS } & =\text { tert-butyldimethylsilyl } \\ \text { TEA } & =\text { Triethylamine } \\ \text { Tf } & =\text { Trifluoromethane sulfonyl } \\ \text { TFA } & =\text { Trifluoroacetic acid } \\ \text { THF } & =\text { Tetrahydrofuran } \\ \text { TIPS } & =\text { Triisopropylsilyl } \\ \text { TMS } & =\text { Trimethylsilyl } \\ \text { Tol } & =\text { Tolyl } \\ \text { Ts } & =4 \text {-toluenesulfonyl (tosyl) } \\ & \end{array}$


[1] Ye, Y.; Yang, D.; Chen, H.; Guo, S.; Yang, Q.; Chen, L.; Zhao, H.; Wang, L. A high-efficiency corrosion inhibitor of $\mathrm{N}$-doped citric acid-based carbon dots for mild steel in hydrochloric acid environment. J. Hazard. Mater., 2020, 381,121019 .

http://dx.doi.org/10.1016/j.jhazmat.2019.121019 PMID: 31442687

[2] Ye, Y; Chen, $\mathrm{H}$; Zou, Y; Shao, H. Study on self-healing and corrosion resistance behaviors of functionalized carbon dot-intercalated graphenebased waterborne epoxy coating. J. Mater. Sci. Technol., 2021, 67, 226-236. http://dx.doi.org/10.1016/j.jmst.2020.06.023

[3] Ye, Y.; Jiang, Z.; Zou, Y.; Chen, H.; Guo, S.; Yiang, Q.; Chen, L. Evaluation of the inhibition behavior of carbon dots on carbon steel in $\mathrm{HCl}$ and $\mathrm{NaCl}$ solutions. J. Mater. Sci. Technol., 2020, 43, 144-153.

http://dx.doi.org/10.1016/j.jmst.2020.01.025

[4] Rudnick, R.L.; Fountain, D.M. Nature and composition of the continental crust: a lower crustal perspective. Rev. Geophys., 1995, 33, 267-309.

http://dx.doi.org/10.1029/95RG01302

[5] (a) Noyori, R. Asymmetric Catalysts in Organic Synthesis; Wiley-VCH: New-York, 1994

(b) Beller, M.; Bolm, C. Transition Metals for Organic Synthesis; WileyVCH: Weinheim, 1998

http://dx.doi.org/10.1002/9783527619399

(c) Jacobsen, E.N.; Pfaltz, A.; Yamamoto, H. Comprehensive Asymmetric Catalysis; Springer: Berlin, 1999

$\mathrm{http}: / / \mathrm{dx}$.doi.org/10.1007/978-3-642-58571-5

(d) Ojima, I. Catalytic Asymmetric Synthesis; Wiley-VCH, 2000

http://dx.doi.org/10.1002/0471721506

(e) Negishi, E. Handbook of Organopalladium Chemistry for Organic Synthesis; John Wiley \& Sons: Hoboken, 2002.

(f) de Meijere, A.; von Zezschwitz, P.; Nüske, H.; Stulgies, B. New cascade and multiple cross-coupling reactions for the efficient construction of complex molecules. J. Organomet. Chem., 2002, 653, 129-140.

http://dx.doi.org/10.1016/S0022-328X(02)01168-3

(g) Beller, M.; Bolm, C. Metals for Organic Synthesis, $2^{\text {nd }}$ ed.; Wiley-VCH: Weinheim, 2004

(h) Tietze, L.F.; Ila, H.; Bell, H.P. Enantioselective palladium-catalyzed transformations. Chem. Rev., 2004, 104(7), 3453-3516.

http://dx.doi.org/10.1021/cr030700x PMID: 15250747

(i) Ramón, D.J.; Yus, M. In the arena of enantioselective synthesis, titanium complexes wear the laurel wreath. Chem. Rev., 2006, 106(6), 2126-2208.

http://dx.doi.org/10.1021/cr040698p PMID: 16771446

(j) Pellissier, H.; Clavier, H. Cobalt-catalyzed selective hydrogenation of nitriles to secondary imines. Chem. Rev., 2014, 114, 2775-2823.

http://dx.doi.org/10.1021/cr4004055 PMID: 24428605

(k) Pellissier, H. Recent advances in enantioselective vanadium-catalyzed transformations. Coord. Chem. Rev., 2015, 284, 93-110.

http://dx.doi.org/10.1016/j.ccr.2014.09.014

(1) Pellissier, H. Enantioselective silver-catalyzed transformations. Chem. Rev., 2016, 116(23), 14868-14917.

http://dx.doi.org/10.1021/acs.chemrev.6b00639 PMID: 27960274

[6] (a) Thankachan, A.P.; Asha, S.; Sindhu, K.S.; Anilkumar, G. An overview of Zn-catalyzed enantioselective aldol type $\mathrm{C} \square \mathrm{C}$ bond formation. $R S C A d v$., 2015, 5, 62179-62193.

http://dx.doi.org/10.1039/C5RA10102F

(b) Bauer, T. Enantioselective dialkylzinc-mediated alkynylation, arylation and alkenylation of carbonyl compounds. Coord. Chem. Rev., 2015, 299, 83150.

http://dx.doi.org/10.1016/j.ccr.2015.03.025

(c) Saranya, S.; Harry, N.A.; Ujwaldev, S.M.; Anilkumar, G. Recent advances and perspectives on the zinc-catalyzed nitroaldol (Henry) reaction. Asian J. Org. Chem., 2017, 6, 1349-1360. http://dx.doi.org/10.1002/ajoc.201700290

(d) Wu, H-L.; Chang, C-A.; Wu, P-Y.; Uang, B-J. Recent developments in Zn-catalyzed asymmetric addition reaction to ketones: syntheses of chiral tertiary alcohols. Tetrahedron Lett., 2017, 58, 706-710.

http://dx.doi.org/10.1016/j.tetlet.2017.01.034

(e) Rohit, K.R.; Ujwaldev, S.M.; Krishnan, K.K.; Anilkumar, G. Recent developments and perspectives in the zinc-catalysed Michael addition. Asian J. Org. Chem., 2018, 7, 85-102.

http://dx.doi.org/10.1002/ajoc.201700491

[7] (a) Ho, T-L. Tandem Organic Reactions; Wiley: New York, 1992

(b) Bunce, R.A. Recent advances in the use of tandem reactions for organic synthesis. Tetrahedron, 1995, 51, 13103-13159.

http://dx.doi.org/10.1016/0040-4020(95)00649-S

(c) Padwa, A.; Weingarten, M.D. Cascade processes of metallo carbenoids. Chem. Rev., 1996, 96(1), 223-270.

http://dx.doi.org/10.1021/cr950022h PMID: 11848752

(d) Tietze, L.F.; Rackelmann, N. Domino reactions in the synthesis of heterocyclic natural products and analogs. Pure Appl. Chem., 2004, 76, 1967-1983. http://dx.doi.org/10.1351/pac200476111967

(e) Fogg, D.E.; dos Santos, E.N. Tandem catalysis: a taxonomy and illustrative review. Coord. Chem. Rev., 2004, 248, 2365-2379.

http://dx.doi.org/10.1016/j.ccr.2004.05.012 (f) Wasilke, J-C.; Obrey, S.J.; Baker, R.T.; Bazan, G.C. Concurrent tandem catalysis. Chem. Rev., 2005, 105(3), 1001-1020.

http://dx.doi.org/10.1021/cr020018n PMID: 15755083

(g) Nicolaou, K.C.; Edmonds, D.J.; Bulger, P.G. Cascade reactions in total synthesis. Angew. Chem. Int. Ed. Engl., 2006, 45(43), 7134-7186.

http://dx.doi.org/10.1002/anie.200601872 PMID: 17075967

(h) Chapman, C.J.; Frost, C.G. Tandem and domino catalytic strategies for enantioselective synthesis. Synthesis, 2007, 2007(1), 1-21.

http://dx.doi.org/10.1055/s-2006-950379

(i) Padwa, A.; Bur, S.K. The domino way to heterocycles. Tetrahedron, 2007, 63(25), 5341-5378.

http://dx.doi.org/10.1016/j.tet.2007.03.158 PMID: 17940591

(j) D'Souza, D.M.; Müller, T.J.J. Multi-component syntheses of heterocycles by transition-metal catalysis. Chem. Soc. Rev., 2007, 36(7), 1095-1108.

http://dx.doi.org/10.1039/B608235C PMID: 17576477

(k) Alba, A-N.; Companyo, X.; Viciano, M.; Rios, R. Organocatalytic Domino reactions. Curr. Org. Chem., 2009, 13, 1432-1474.

http://dx.doi.org/10.2174/138527209789055054

(1) Chem. Soc. Rev., 2009, 38

(m) Nicolaou, K.C.; Chen, J.S. The art of total synthesis through cascade reactions. Chem. Soc. Rev., 2009, 38(11), 2993-3009.

http://dx.doi.org/10.1039/b903290h PMID: 19847336

(n) de Graaff, C.; Ruijter, E.; Orru, R.V.A. Recent developments in asymmetric multicomponent reactions. Chem. Soc. Rev., 2012, 4l(10), 3969-4009.

http://dx.doi.org/10.1039/c2cs15361k PMID: 22546840

(o) Hayashi, Y. Pot economy and one-pot synthesis. Chem. Sci. (Camb.), 2016, $7(2), 866-880$.

http://dx.doi.org/10.1039/C5SC02913A PMID: 28791118

[8] (a) Posner, G.H. Multicomponent one-pot annulations forming 3 to 6 bonds. Chem. Rev., 1986, 86, 831-844.

http://dx.doi.org/10.1021/cr00075a007

(b) Tietze, L.F.; Beifuss, U. Sequential transformations in organic chemistry: a synthetic strategy with a future. Angew. Chem. Int. Ed. Engl., 1993, 32, 131-163.

http://dx.doi.org/10.1002/anie.199301313

(c) Tietze, L.F. Domino reactions in organic synthesis. Chem. Rev., 1996, 96(1), 115-136.

http://dx.doi.org/10.1021/cr950027e PMID: 11848746

(d) Parsons, P.J.; Penkett, C.S.; Shell, A.J. Tandem reactions in organic synthesis: novel strategies for natural product elaboration and the development of new synthetic methodology. Chem. Rev., 1996, 96(1), 195-206.

http://dx.doi.org/10.1021/cr950023+ PMID: 11848750

(e) Dalko, P.I.; Moisan, L. In the golden age of organocatalysis. Angew. Chem. Int. Ed. Engl., 2004, 43(39), 5138-5175.

http://dx.doi.org/10.1002/anie.200400650 PMID: 15455437

(f) Ramón, D.J.; Yus, M. Asymmetric Multicomponent Reactions (AMCRs): the new frontier. Angew. Chem. Int. Ed. Engl., 2005, 44(11), 1602-1634.

http://dx.doi.org/10.1002/anie.200460548 PMID: 15719349

(g) Zhu, J.; Bienaymé, H. Multicomponent Reactions; Wiley-VCH: Weinheim, 2005

http://dx.doi.org/10.1002/3527605118

(h) Tietze, L.F.; Brasche, G.; Gericke, K. Domino Reactions in Organic Synthesis; Wiley-VCH: Weinheim, 2006.

http://dx.doi.org/10.1002/9783527609925

(i) Pellissier, H. Asymmetric domino reactions. Part B: reactions based on the use of chiral catalysts and biocatalysts. Tetrahedron, 2006, 62, 2143-2173.

http://dx.doi.org/10.1016/j.tet.2005.10.041

(j) Pellissier, H. Asymmetric domino reactions. Part A: reactions based on the use of chiral auxiliaries. Tetrahedron, 2006, 62, 1619-1665.

http://dx.doi.org/10.1016/j.tet.2005.10.040

(k) Enders, D.; Grondal, C.; Hüttl, M.R.M. Asymmetric organocatalytic domino reactions. Angew. Chem. Int. Ed. Engl., 2007, 46(10), 1570-1581. http://dx.doi.org/10.1002/anie.200603129 PMID: 17225236

(1) Guillena, G.; Ramon, D.J.; Yus, M. Organocatalytic enantioselective multicomponent reactions (OEMCRs). Tetrahedron Asymmetry, 2007, 18, 693700 .

http://dx.doi.org/10.1016/j.tetasy.2007.03.002

(m) Touré, B.B.; Hall, D.G. Natural product synthesis using multicomponent reaction strategies. Chem. Rev., 2009, 109(9), 4439-4486.

http://dx.doi.org/10.1021/cr800296p PMID: 19480390

(n) Orru, R.V.A.; Ruijter, E. Synthesis of Heterocycles via Multicomponent Reactions, Topics in Heterocyclic Chemistry; Springer: Berlin, 2010.

(o) Pellissier, H. Recent developments in asymmetric organocatalytic Domino reactions. Adv. Synth. Catal., 2012, 354, 237-294.

http://dx.doi.org/10.1002/adsc.201100714

(p) Clavier, H.; Pellissier, H. Recent developments in enantioselective metalcatalyzed Domino reactions. Adv. Synth. Catal., 2012, 354, 3347-3403. http://dx.doi.org/10.1002/adsc.201200254

(q) Pellissier, H. Stereocontrolled Domino reactions. Chem. Rev., 2013, $113(1), 442-524$

http://dx.doi.org/10.1021/cr300271k PMID: 23157479

(r) Pellissier, H. Asymmetric Domino Reactions; Royal Society of Chemistry: Cambridge, 2013.

(s) Tietze, L.F. Domino Reactions - Concepts for Efficient Organic Synthesis; Wiley-VCH: Weinheim, 2014 
http://dx.doi.org/10.1002/9783527671304

(t) Zhu, J.; Wang, Q.; Wang, M. Multicomponent Reactions in Organic Synthesis; Wiley: Weinheim, 2014

http://dx.doi.org/10.1002/9783527678174

(u) Herrera, R.P.; Marques-Lopez, E. Multicomponent Reactions: Concepts and Applications for Design and Synthesis; Wiley: Weinheim, 2015.

(v) Snyder, S.A. Science of synthesis In: Applications of Domino Transformations in Organic Synthesis; Thieme Verlag: Stuttgart, 2016.

(w) Pellissier, H. Recent developments in enantioselective metal-catalyzed Domino reactions. Adv. Synth. Catal., 2016, 358, 2194-2259.

http://dx.doi.org/10.1002/adsc.201600462

(x) Pellissier, H. Recent developments in enantioselective metal-catalyzed domino reactions. Adv. Synth. Catal., 2019, 361, 1733-1755.

http://dx.doi.org/10.1002/adsc.201801371

[9] Prasad, A.S. Zinc deficiency. BMJ, 2003, 326(7386), 409-410.

http://dx.doi.org/10.1136/bmj.326.7386.409 PMID: 12595353

[10] Prakash, A.; Bharti, K.; Majeed, A.B. Zinc: indications in brain disorders. Fundam. Clin. Pharmacol., 2015, 29(2), 131-149.

http://dx.doi.org/10.1111/fcp.12110 PMID: 25659970

[11] Cherasse, Y.; Urade, Y. Dietary zinc acts as a sleep modulator. Int. J. Mol. Sci., 2017, 18(11), 2334-2346. http://dx.doi.org/10.3390/ijms18112334 PMID: 29113075

[12] Broadley, M.R.; White, P.J.; Hammond, J.P.; Zelko, I.; Lux, A. Zinc in plants. New Phytol., 2007, 173(4), 677-702.

http://dx.doi.org/10.1111/j.1469-8137.2007.01996.x PMID: 17286818

[13] Brandt, E.G.; Hellgren, M.; Brinck, T.; Bergman, T.; Edholm, O. Molecular dynamics study of zinc binding to cysteines in a peptide mimic of the alcohol dehydrogenase structural zinc site. Phys. Chem. Chem. Phys., 2009, 11(6), 975-983.

http://dx.doi.org/10.1039/B815482A PMID: 19177216

[14] Rout, G.R.; Das, P. Effect of metal toxicity on plant growth and metabolism: I. Zinc. Agronomie, 2003, 23, 3-11.

http://dx.doi.org/10.1051/agro:2002073

[15] Smith, S.E.; Larson, E.J. Zinc toxicity in rats; antagonistic effects of copper and liver. J. Biol. Chem., 1946, 163, 29-38. http://dx.doi.org/10.1016/S0021-9258(17)41344-5 PMID: 21023625

[16] Muyssen, B.T.; De Schamphelaere, K.A.; Janssen, C.R.; Janssen, C.R. Mechanisms of chronic waterborne $\mathrm{Zn}$ toxicity in Daphnia magna. Aquat. Toxicol., 2006, 77(4), 393-401.

http://dx.doi.org/10.1016/j.aquatox.2006.01.006 PMID: 16472524

[17] Fosmire, G.J. Zinc toxicity. Am. J. Clin. Nutr., 1990, 51(2), 225-227. http://dx.doi.org/10.1093/ajen/51.2.225 PMID: 2407097

[18] Ciubotariu, D.; Ghiciuc, C.M.; Lupu $\square$ oru, C.E. Zinc involvement in opioid addiction and analgesia--should zinc supplementation be recommended for opioid-treated persons? Subst. Abuse Treat. Prev. Policy, 2015, 10, 29. http://dx doi org/10.1186/s13011-015-0025-2 PMID: 26238243

[19] Lowicki, D.; Bas, S.; Mlynarski, J. Chiral zinc catalysts for asymmetric synthesis. Tetrahedron, 2015, 71, 1339-1394.

http://dx.doi.org/10.1016/j.tet.2014.12.022

[20] (a) Enthaler, S.; Wu, X-F. Zinc Catalysis: Applications in Organic Synthesis; Wiley: Weinheim, $\mathbf{2 0 1 5}$

http://dx.doi.org/10.1002/9783527675944

(b) Enthaler, S. Rise of the zinc age in homogeneous catalysis? ACS Catal., 2013, 3, 150-158

http://dx.doi.org/10.1021/cs300685q

(c) Wu, X-F.; Neumann, H. Zinc-catalyzed organic synthesis: C $\square$ C, C $\square$ N, $\mathrm{C} \square \mathrm{O}$ bond formation reactions. Adv. Synth. Catal., 2012, 354, 3141-3160. http://dx.doi.org/10.1002/adsc.201200547

[21] Kim, J.H.; Ko, Y.O.; Bouffard, J.; Lee, S.G. Advances in tandem reactions with organozinc reagents. Chem. Soc. Rev., 2015, 44(8), 2489-2507.

http://dx.doi.org/10.1039/C4CS00430B PMID: 25708795

[22] Krishnan, K.K.; Ujwaldev, S.M.; Saranya, S.; Anilkumar, G.; Beller, M. Recent advances and perspectives in the synthesis of heterocycles via zinc catalysis. Adv. Synth. Catal., 2019, 361, 382-404.

http://dx.doi.org/10.1002/adsc. 201800868

[23] Neetha, M.; Rohit, K.R.; Sranya, S.; Anilkumar, G. Zinc-catalysed multicomponent reactions: an overview. ChemistrySelect, 2020, 5, 1054-1070. http://dx.doi.org/10.1002/slct.201904146

[24] (a) Zhang, W.; Loebach, J.L.; Wilson, S.R.; Jacobsen, E.N. Enantioselective epoxidation of unfunctionalized olefins catalyzed by salen manganese complexes. J. Am. Chem. Soc., 1990, 112, 2801-2803.

http://dx.doi.org/10.1021/ja00163a052

(b) Sawamura, M.; Nagata, H.; Sakamoto, H.; Ito, Y. Chiral phosphine ligands modified by crown ethers: an application to palladium-catalyzed asymmetric allylation of. beta.-diketones. J. Am. Chem. Soc., 1992, 114, 2586-2592.

http://dx.doi.org/10.1021/ja00033a035

[25] Trost, B.M.; Ito, H. A direct catalytic enantioselective Aldol reaction via a novel catalyst design. J. Am. Chem. Soc., 2000, 122, 12003-12004. http://dx.doi.org/10.1021/ja003033n

[26] Trost, B.M.; Bartlett, M.J. ProPhenol-catalyzed asymmetric additions by spontaneously assembled dinuclear main group metal complexes. Acc. Chem Res., 2015, 48(3), 688-701. http://dx.doi.org/10.1021/ar500374r PMID: 25650587
[27] Trost, B.M.; Yeh, V.S.C. A dinuclear Zn catalyst for the asymmetric nitroaldol (Henry) reaction. Angew. Chem. Int. Ed. Engl., 2002, 4l(5), 861-863. http://dx.doi.org/10.1002/1521-3773(20020301)41:5<861::AIDANIE861>3.0.CO;2-V PMID: 12491361

[28] (a) Trost, B.M.; Terrell, L.R. A direct catalytic asymmetric Mannich-type reaction to syn-amino alcohols. J. Am. Chem. Soc., 2003, 125(2), 338-339. http://dx.doi.org/10.1021/ja028782e PMID: 12517138

(b) Trost, B.M.; Jaratjaroonphong, J.; Reutrakul, V. A direct catalytic asymmetric Mannich-type reaction via a dinuclear zinc catalyst: synthesis of either anti- or syn- $\alpha$-hydroxy- $\beta$-amino ketones. J. Am. Chem. Soc., 2006, 128(9), 2778-2779.

http://dx.doi.org/10.1021/ja057498v PMID: 16506738

[29] (a) Trost, B.M.; Hitce, J. Direct asymmetric Michael addition to nitroalkenes: vinylogous nucleophilicity under dinuclear zinc catalysis. J. Am. Chem. Soc 2009, 131(13), 4572-4573.

http://dx.doi.org/10.1021/ja809723u PMID: 19281239

(b) Trost, B.M.; Hirano, K. Highly stereoselective synthesis of $\alpha$-alkyl- $\alpha$ hydroxycarboxylic acid derivatives catalyzed by a dinuclear zinc complex. Angew. Chem. Int. Ed. Engl., 2012, 51(26), 6480-6483.

http://dx.doi.org/10.1002/anie.201201116 PMID: 22644705

[30] (a) Trost, B.M.; Weiss, A.H.; von Wangelin, A.J. Dinuclear Zn-catalyzed asymmetric alkynylation of unsaturated aldehydes. J. Am. Chem. Soc., 2006, 128(1), 8-9

http://dx.doi.org/10.1021/ja054871q PMID: 16390095

(b) Trost, B.M.; Quintard, A. Asymmetric catalytic alkynylation of acetaldehyde: application to the synthesis of (+)-tetrahydropyrenophorol. Angew. Chem. Int. Ed. Engl., 2012, 51(27), 6704-6708.

http://dx.doi.org/10.1002/anie.201203035 PMID: 22674869

[31] Trost, B.M.; Müller, C. Asymmetric Friedel-Crafts alkylation of pyrroles with nitroalkenes using a dinuclear zinc catalyst. J. Am. Chem. Soc., 2008, 130(8), 2438-2439.

http://dx.doi.org/10.1021/ja711080y PMID: 18237176

[32] Trost, B.M.; Hirano, K. Dinuclear zinc catalyzed asymmetric spirannulation reaction: an umpolung strategy for formation of $\alpha$-alkylated- $\alpha$ hydroxyoxindoles. Org. Lett., 2012, 14(10), 2446-2449. http://dx.doi.org/10.1021/ol300577y PMID: 22545918

[33] Smirnov, P.; Mathew, J.; Nijs, A.; Katan, E.; Karni, M.; Bolm, C.; Apeloig, Y.; Marek, I. One-pot zinc-promoted asymmetric alkynylation/brook-type rearrangement/ene-allene cyclization: highly selective formation of three new bonds and two stereocenters in acyclic systems. Angew. Chem. Int. Ed. Engl., 2013, 52(51), 13717-13721.

http://dx.doi.org/10.1002/anie.201306749 PMID: 24155160

[34] Song, X.; Liu, J.; Liu, M-M.; Wang, X.; Zhang, Z-F.; Wang, M-C.; Chang, J. Tetrahedron, 2014, 70, 5468-5474

http://dx.doi.org/10.1016/j.tet.2014.06.109

[35] Trost, B.M.; Hung, C-I.; Saget, T.; Gnanamani, E. Branched aldehydes as linchpins for the enantioselective and stereodivergent synthesis of 1,3aminoalcohols featuring a quaternary stereocentre. Nature Catalysis, 2018, 1, 523-530.

http://dx.doi.org/10.1038/s41929-018-0093-6

[36] Trost, B.M. Gnanamani, E.; Hung C.J.; Kalnmals, C.A. Synthesis of chiral, densely substituted pyrrolidones via phosphine-catalyzed cycloisomerization. Org. Lett., 2019, $21(6), 1890-1894$

http://dx.doi.org/10.1021/acs.orglett.9b00496 PMID: 30829494

[37] Trost, B.M.; Gnanamani, E. Enantio- and diastereoselective double Mannich reaction between ketones and imines catalyzed by Zn-prophenol. Org. Lett. 2020, 22(4), 1675-1680.

http://dx.doi.org/10.1021/acs.orglett.0c00318 PMID: 3201758

[38] Tao, B-K.; Yang, H.; Hua, Y-Z.; Wang, M-C. Dinuclear zinc synergistic catalytic asymmetric phospha-Michael/Michael cascade reaction: synthesis of 1,2,3-trisubstituted indanes bearing phosphoryl groups. Org. Biomol. Chem., 2019, 17(17), 4301-4310

http://dx.doi.org/10.1039/C9OB00544G PMID: 30969299

[39] Miao, Y-H.; Hua, Y-Z; Wang, M-C. Dinuclear zinc cooperative catalytic three-component reactions for highly enantioselective synthesis of 3,3'dihydrofuran spirooxindoles. Org. Biomol. Chem., 2019, 17(30), 7172-7181. http://dx.doi.org/10.1039/C9OB01233H PMID: 31310252

[40] (a) Xu, P-W.; Yu, J-S.; Chen, C.; Cao, Z-Y.; Zhou, F.; Zhou, J. Catalytic enantioselective construction of spiro quaternary carbon stereocenters. ACS Catal., 2019, 9, 1820-1882.

http://dx.doi.org/10.1021/acscatal.8b03694

(b) Pellissier, H. Synthesis of chiral 3-substituted 3-amino-2-oxindoles through enantioselective catalytic Domino and Tandem reactions. Synthesis, 2019, $51,1311-1318$

http://dx.doi.org/10.1055/s-0037-1610350

[41] Guo, Y-J.; Guo, X.; Kong, D-Z.; Lu, H-J.; Liu, L-T.; Hua, Y-Z.; Wang, M-C Catalytic asymmetric synthesis of tetrahydrofuran spirooxindoles via dinuclear zinc catalyst. J. Org. Chem., 2020, 85(6), 4195-4206. http://dx.doi.org/10.1021/acs.joc.9b03378 PMID: 32083864

[42] Hua, Y-Z.; Han, X-W.; Yang, X-C.; Song, X.; Wang, M-C.; Chang, J-B. Photostable p-type dye-sensitized photoelectrochemical cells for water reduction. J. Org. Chem., 2014, 79, 11696-11699.

[43] Hua, Y-Z.; Liu, M-M.; Huang, P-J.; Song, X.; Wang, M-C.; Chang, J-B. A new strategy for enantioselective construction of multisubstituted five- 
membered oxygen heterocycles via a Domino Michael/Hemiketalization reaction. Chemistry, 2015, $21(34), 11994-11998$.

http://dx.doi.org/10.1002/chem.201501655 PMID: 26177976

[44] Liu, M-M.; Yang, X-C.; Hua, Y-Z.; Chang, J-B.; Wang, M-C. Synthesis of chiral bispirotetrahydrofuran oxindoles by cooperative bimetallic-catalyzed asymmetric Cascade Reaction. Org. Lett., 2019, 21(7), 2111-2115.

http://dx.doi.org/10.1021/acs.orglett.9b00386 PMID: 30865463

[45] Liu, M-M.; Yang, X-C.; Hua, Y-Z.; Chang, J-B.; Wang, M-C. Dinuclear zinc-catalyzed asymmetric tandem reaction of $\alpha$-hydroxy-1-indanone: access to spiro[1-indanone-5,2'- $\gamma$-butyrolactones]. Org. Lett., 2019, 21(17), 70897093 .

http://dx.doi.org/10.1021/acs.orglett.9b02658 PMID: 31456408

[46] Yang, X-C.; Xu, M.; Wang, J-B.; Liu, M-M.; Mathey, F.; Hua, Y-Z.; Wang, $\mathrm{M}-\mathrm{C}$. Enantioselective synthesis of indanone spiro-isochromanone derivatives via a dinuclear zinc-catalyzed Michael/transesterification tandem reaction. Org. Biomol. Chem., 2020, 18(20), 3917-3926.

http://dx.doi.org/10.1039/D0OB00541J PMID: 32400845

[47] Yang, X-C.; Liu, M-M.; Mathey, F.; Yang, H.; Hua, Y.Z.; Wang, M.C. Access to chiral 2,5-pyrrolidinyl dispirooxindoles via dinuclear zinccatalyzed asymmetric Cascade reactions. J. Org. Chem., 2019, 84(12), 77627775 .

http://dx.doi.org/10.1021/acs.joc.9b00645 PMID: 31145619

[48] Stanley, L.M.; Sibi, M.P. Privileged Chiral Ligands and Catalysts; Zhou, Q., Ed.; Wiley: Weinheim, 2011,pp. 171-219.

http://dx.doi.org/10.1002/9783527635207.ch5

(b) Desimoni, G.; Faita, G.; Jørgensen, K.A. Update 1 of: C2-symmetric chiral bis(oxazoline) ligands in asymmetric catalysis. Chem. Rev., 2011, 111(11), PR284-PR437.

http://dx.doi.org/10.1021/cr100339a PMID: 22077602

[49] Junge, K.; Möller, K.; Wendt, B.; Das, S.; Gördes, D.; Thurow, K.; Beller, M. Enantioselective zinc-catalyzed hydrosilylation of ketones using pybox or pybim ligands. Chem. Asian J., 2012, 7(2), 314-320.

http://dx.doi.org/10.1002/asia.201100561 PMID: 22174103

[50] Miyabe, H.; Asada, R.; Toyoda, A.; Takemoto, Y. Enantioselective cascade radical addition-cyclization-trapping reactions. Angew. Chem. Int. Ed. Engl., 2006, 45(35), 5863-5866.

http://dx.doi.org/10.1002/anie.200602042 PMID: 16874830

[51] (a) Ma, J-A.; Cahard, D. Towards perfect catalytic asymmetric synthesis: dual activation of the electrophile and the nucleophile. Angew. Chem. Int. Ed. Engl., 2004, 43(35), 4566-4583.

http://dx.doi.org/10.1002/anie.200300635 PMID: 15352183

(b) Shao, Z.; Zhang, H. Combining transition metal catalysis and organocatalysis: a broad new concept for catalysis. Chem. Soc. Rev., 2009, 38(9), 2745 2755 .

http://dx.doi.org/10.1039/b901258n PMID: 19690751

(c) Zhong, C.; Shi, X. When organocatalysis meets transition-metal catalysis. Eur. J. Org. Chem., 2010, 2999-3025.

http://dx.doi.org/10.1002/ejoc.201000004

(d) Rueping, M.; Koenigs, R.M.; Atodiresei, I. Unifying metal and Brønsted acid catalysis--concepts, mechanisms, and classifications. Chemistry, 2010 , 16(31), 9350-9365.

http://dx.doi.org/10.1002/chem.201001140 PMID: 20665582

(e) Zhou, J. Recent advances in multicatalyst promoted asymmetric tandem reactions. Chem. Asian J., 2010, 5(3), 422-434.

http://dx.doi.org/10.1002/asia.200900458 PMID: 20052703

(f) Ambrosini, L.M.; Lambert, T.H. Multicatalysis: advancing synthetic efficiency and inspiring discovery. ChemCatChem, 2010, 2, 1373-1380. http://dx.doi.org/10.1002/cctc.200900323

(g) Piovesana, S.; Scarpino Schietroma, D.M.; Bella, M. Multiple catalysis with two chiral units: an additional dimension for asymmetric synthesis. Angew. Chem. Int. Ed. Engl., 2011, 50(28), 6216-6232.

http://dx.doi.org/10.1002/anie.201005955 PMID: 21608089

(h) Shibasaki, M.; Kanai, M.; Matsunaga, S.; Kumagai, N. Multimetallic multifunctional catalysts for asymmetric reactions. Top. Organomet. Chem., 2011, 37, 1-30.

http://dx.doi.org/10.1007/3418_2011_1

(i) Patil, N.T. Merging metal and N-heterocyclic carbene catalysis: on the way to discovering enantioselective organic transformations. Angew. Chem. Int. Ed. Engl., 2011, 50(8), 1759-1761.

http://dx.doi.org/10.1002/anie.201006866 PMID: 21271627

(j) Patil, N.T.; Shinde, V.S.; Gajula, B. A one-pot catalysis: the strategic classification with some recent examples. Org. Biomol. Chem., 2012, 10(2), 211224.

http://dx.doi.org/10.1039/C1OB06432K PMID: 22072256

(k) Allen, A.E.; Macmillan, D.W.C. Synergistic catalysis: a powerful synthetic strategy for new reaction development. Chem. Sci. (Camb.), 2012, 2012(3), 633-658

http://dx.doi.org/10.1039/c2sc00907b PMID: 22518271

(1) Park, J.; Hong, S. Cooperative bimetallic catalysis in asymmetric transformations. Chem. Soc. Rev., 2012, 4l(21), 6931-6943.

http://dx.doi.org/10.1039/c2cs35129c PMID: 22842925

(m) Du, Z.; Shao, Z. Combining transition metal catalysis and organocatalysis--an update. Chem. Soc. Rev., 2013, 42(3), 1337-1378.

http://dx.doi.org/10.1039/C2CS35258C PMID: 23154522 (n) Schindler, C.S.; Jacobsen, E.N. Chemistry. A new twist on cooperative catalysis. Science, 2013, 340(6136), 1052-1053.

http://dx.doi.org/10.1126/science.1238769 PMID: 23723222

(o) Pellissier, H. Recent developments in enantioselective multicatalysed Tandem reactions. Tetrahedron, 2013, 69, 7171-7210.

http://dx.doi.org/10.1016/j.tet.2013.06.020

(p) Pellissier, H. Enantioselective Multicatalysed Tandem Reactions; Royal Society of Chemistry: Cambridge, 2014

(q) Chen, D-F.; Han, Z-Y.; Zhou, X-L.; Gong, L-Z. Asymmetric organocatalysis combined with metal catalysis: concept, proof of concept, and beyond. Acc. Chem. Res., 2014, 47(8), 2365-2377.

http://dx.doi.org/10.1021/ar500101a PMID: 24911184

(r) Matsunaga, S.; Shibasaki, M. Recent advances in cooperative bimetallic asymmetric catalysis: dinuclear Schiff base complexes. Chem. Commun (Camb.), 2014, 50(9), 1044-1057.

http://dx.doi.org/10.1039/C3CC47587E PMID: 24281133

(s) Parmar, D.; Sugiono, E.; Raja, S.; Rueping, M. Complete field guide to asymmetric BINOL-phosphate derived Brønsted acid and metal catalysis: history and classification by mode of activation; Brønsted acidity, hydrogen bonding, ion pairing, and metal phosphates. Chem. Rev., 2014, 114(18), 9047-9153.

http://dx.doi.org/10.1021/cr5001496 PMID: 25203602

(t) Lohr, T.L.; Marks, T.J. Orthogonal Tandem catalysis. Nat. Chem., 2015, 7(6), 477-482.

http://dx.doi.org/10.1038/nchem.2262 PMID: 25991525

(u) Inamdar, S.M.; Shinde, V.S.; Patil, N.T. Enantioselective cooperative catalysis. Org. Biomol. Chem., 2015, 13(30), 8116-8162.

http://dx.doi.org/10.1039/C5OB00986C PMID: 26123696

(v) Zhou, J. Multicatalyst System in Asymmetric Catalysis; Wiley: Weinheim, 2015.

(w) Galvan, A.; Fananas, F.J.; Rodriguez, F. Multicomponent and multicatalytic reactions - a synthetic strategy inspired by nature. Eur. J. Inorg. Chem., 2016, 1306-1313.

http://dx.doi.org/10.1002/ejic.201501287

(x) Afewerki, S.; Córdova, A. Combinations of aminocatalysts and metal catalysts: a powerful cooperative approach in selective organic synthesis. Chem. Rev., 2016, $116(22), 13512-13570$.

http://dx.doi.org/10.1021/acs.chemrev.6b00226 PMID: 27723291

[52] Guan, X-Y.; Yang, L-P.; Hu, W. Cooperative catalysis in multicomponent reactions: highly enantioselective synthesis of $\gamma$-hydroxyketones with a quaternary carbon stereocenter. Angew. Chem. Int. Ed. Engl., 2010, 49(12), 2190-2192.

http://dx.doi.org/10.1002/anie.200904905 PMID: 19894243

[53] Ohara, M.; Nakamura, S.; Shibata, N. Direct enantioselective threecomponent Kabachnik-fields reaction catalyzed by chiral bis(imidazoline)zinc(II) catalysts. Adv. Synth. Catal., 2011, 353, 3285-3289.

http://dx.doi.org/10.1002/adsc.201100482

[54] Tan, F.; Lu, L-Q.; Yang, Q-Q.; Guo, W.; Bian, Q.; Chen, J-R.; Xiao, W-J. Enantioselective cascade Michael addition/cyclization reactions of 3-nitro$2 \mathrm{H}$-chromenes with 3-isothiocyanato oxindoles: efficient synthesis of functionalized polycyclic spirooxindoles. Chemistry, 2014, 20(12), 3415-3420. http://dx.doi.org/10.1002/chem.201303583 PMID: 24677230

[55] Zhao, J-Q.; Wu, Z-J.; Zhou, M-Q.; Xu, X-Y.; Zhang, X-M.; Yuan, W-C. ZnCatalyzed diastereo- and enantioselective Cascade reaction of 3isothiocyanato oxindoles and 3-nitroindoles: stereocontrolled syntheses of polycyclic spirooxindoles. Org. Lett., 2015, $17(20), 5020-5023$. http://dx.doi.org/10.1021/acs.orglett.5b02489 PMID: 26412346

[56] Yue, D-F.; Zhao, J-Q.; Chen, Y-Z.; Zhang, X-M.; Xu, X-Y.; Yuan, W-C. Zinc-Catalyzed enantioselective dearomative $[3+2]$ cycloaddition reaction of 3-nitrobenzothiophenes and 3-nitrothieno[2,3-b]yridine with 3-isothiocyanato oxindoles. Adv. Synth. Catal., 2018, 360, 1420-1425.

http://dx.doi.org/10.1002/adsc.201701557

[57] Z., J.-Q.; Zhou, X.-J.; Chen, Y.-Z.; Xu, X.-Y.; Zhang, X. M.; Yuan, W.-C. Zn-Catalyzed diastereo- and enantioselective dearomative [3+2] cycloaddition reaction of 2-nitroindoles and 2-nitrobenzothiophenes. Adv. Synth. Catal., 2018, 360, 2482-2487.

http://dx.doi.org/10.1002/adsc.201800266

[58] Masson, G.; Lalli, C.; Benohoud, M.; Dagousset, G. Catalytic enantioselective $[4+2]$-cycloaddition: a strategy to access aza-hexacycles. Chem. Soc. Rev., 2013, 42(3), 902-923.

http://dx.doi.org/10.1039/C2CS35370A PMID: 23172010

[59] Chu, J.C.K.; Dalton, D.M.; Rovis, T. Zn-catalyzed enantio- and diastereoselective formal $[4+2]$ cycloaddition involving two electron-deficient partners: asymmetric synthesis of piperidines from 1-azadienes and nitro-alkenes. $J$. Am. Chem. Soc., 2015, 137(13), 4445-4452.

http://dx.doi.org/10.1021/jacs.5b00033 PMID: 25821893

[60] Zhao, S.; Cheng, S.; Liu, H.; Zhang, J.; Liu, M.; Yuan, W.; Zhang, X. Synthesis of chiral $[2,3]$-fused indolines through enantioselective dearomatization inverse-electron-demand Diels-Alder reaction/oxidation of indoles with 2-(2-nitrovinyl)-1,4-benzoquinone. Chem. Commun. (Camb.), 2020, 56(30), 4200-4203.

http://dx.doi.org/10.1039/D0CC00693A PMID: 32167511

[61] (a) Liu, X.; Lin, L.; Feng, X. Chiral N,N'-dioxides: new ligands and organocatalysts for catalytic asymmetric reactions. Acc. Chem. Res., 2011, 44(8), 574-587. 
http://dx.doi.org/10.1021/ar200015s PMID: 21702458

(b) Liu, X; Lin, L.; Feng, X.; Chiral, N. N -dioxide ligands: synthesis, coordination chemistry and asymmetric catalysis. Org. Chem. Front., 2014, 1, 298-302.

http://dx.doi.org/10.1039/c3qo00059a

[62] Chen, W ; Cai, Y · Fu, X ; Liu, X; Lin, L F Feng, X Enantioselective one-pot synthesis of 2-amino-4-(indol-3-yl)-4H-chromenes. Org. Lett., 2011, 13(18), 4910-4913.

http://dx.doi.org/10.1021/ol2019949 PMID: 21859119

[63] Kang, T; Cao, W.; Hou, L.; Tang, Q.; Zou, S.; Liu, X.; Feng, X. Chira Zinc(II)-catalyzed enantioselective Tandem $\alpha$-alkenyl addition/proton shift reaction of silyl enol ethers with ketimines. Angew. Chem. Int. Ed. Engl., 2019, $58(8), 2464-2468$.

http://dx.doi.org/10.1002/anie.201810961 PMID: 30644632

[64] $\mathrm{Xu}, \mathrm{C}$; Wang, $\mathrm{K}$; Li, $\mathrm{D}$; Lin, L; Feng, X. Asymmetric synthesis of oxabridged oxazocines through a catalytic $\mathrm{Rh}^{\mathrm{II}} / \mathrm{Zn}^{\mathrm{II}}$ relay [4+3] cycloaddition reaction. Angew. Chem. Int. Ed. Engl., 2019, 58(51), 18438-18442. http://dx.doi.org/10.1002/anie.201910898 PMID: 31613040

[65] Yin, C; Hu, X-Q ; Hui, X-P ; Xu, P-F Alkylzinc-mediated addition of alkynes to N-tosylaldimines: enantioselective synthesis of (E)-(2-En-3-ynyl)amines. Adv. Synth. Catal., 2009, 351, 1512-1516.

http://dx.doi.org/10.1002/adsc.200900219

[66] Ishihara, J.; Nakadachi, S.; Watanabe, Y.; Hatakeyama, S. Lewis acid template-catalyzed asymmetric diels-alder reaction. J. Org. Chem., 2015, 80(4), 2037-2041.

http://dx.doi.org/10.1021/acs.joc.5b00055 PMID: 25621816
[67] Huang, H.; Zong, H.; Bian, G.; Song, L. Chemo- and enantioselective addition and $\beta$-hydrogen transfer reduction of carbonyl compounds with diethylzinc reagent in one pot catalyzed by a single chiral organometallic catalyst J. Org. Chem., 2015, 80(24), 12614-12619.

http://dx.doi.org/10.1021/acs.joc.5b01871 PMID: 26579727

[68] Weglarz, I. Szewczyk, M.; Mlynarski, J. Zinc acetate catalyzed enantioselective reductive aldol reaction of ketones. Adv. Synth. Catal., 2020,362, 1532 1536

http://dx.doi.org/10.1002/adsc.201901457

[69] Zani, L; Eichhorn, T; Bolm, C. Dimethylzinc-mediated, enantioselective synthesis of propargylic amines. Chemistry, 2007, 13(9), 2587-2600. http://dx.doi.org/10.1002/chem.200601347 PMID: 17186561

[70] Shiomi, N.; Kuroda, M.; Nakamura, S. Desymmetrization of aziridine with malononitrile using cinchona alkaloid amide/zinc(II) catalysts. Chem. Commun. (Camb.), 2017, 53(11), 1817-1820.

http://dx.doi.org/10.1039/C6CC09457K PMID: 28106898

[71] Chen, T.; Gan, L.; Wang, R.; Deng, Y.; Peng, F.; Lautens, M.; Shao, Z. Rhodium(I)/Zn $(\mathrm{OTf})_{2}$-catalyzed asymmetric ring opening/cyclopropanation of oxabenzonorbornadienes with phosphorus ylides. Angew. Chem. Int. Ed. Engl., 2019, 58(44), 15819-15823.

http://dx.doi.org/10.1002/anie.201909596 PMID: 31489736

[72] Liu, R.; Yang, S.; Chen, Z.; Kong, X.; Ding, H.; Fang, X. Lewis-acidcatalyzed asymmetric alkynylation of alkynyl 1,2-diketones: controllable formation of $3(2 H)$-furanones and $\alpha$-hydroxy ketones. Org. Lett., 2020 , 22(17), 6948-6953.

http://dx.doi.org/10.1021/acs.orglett.0c02505 PMID: 32822188 